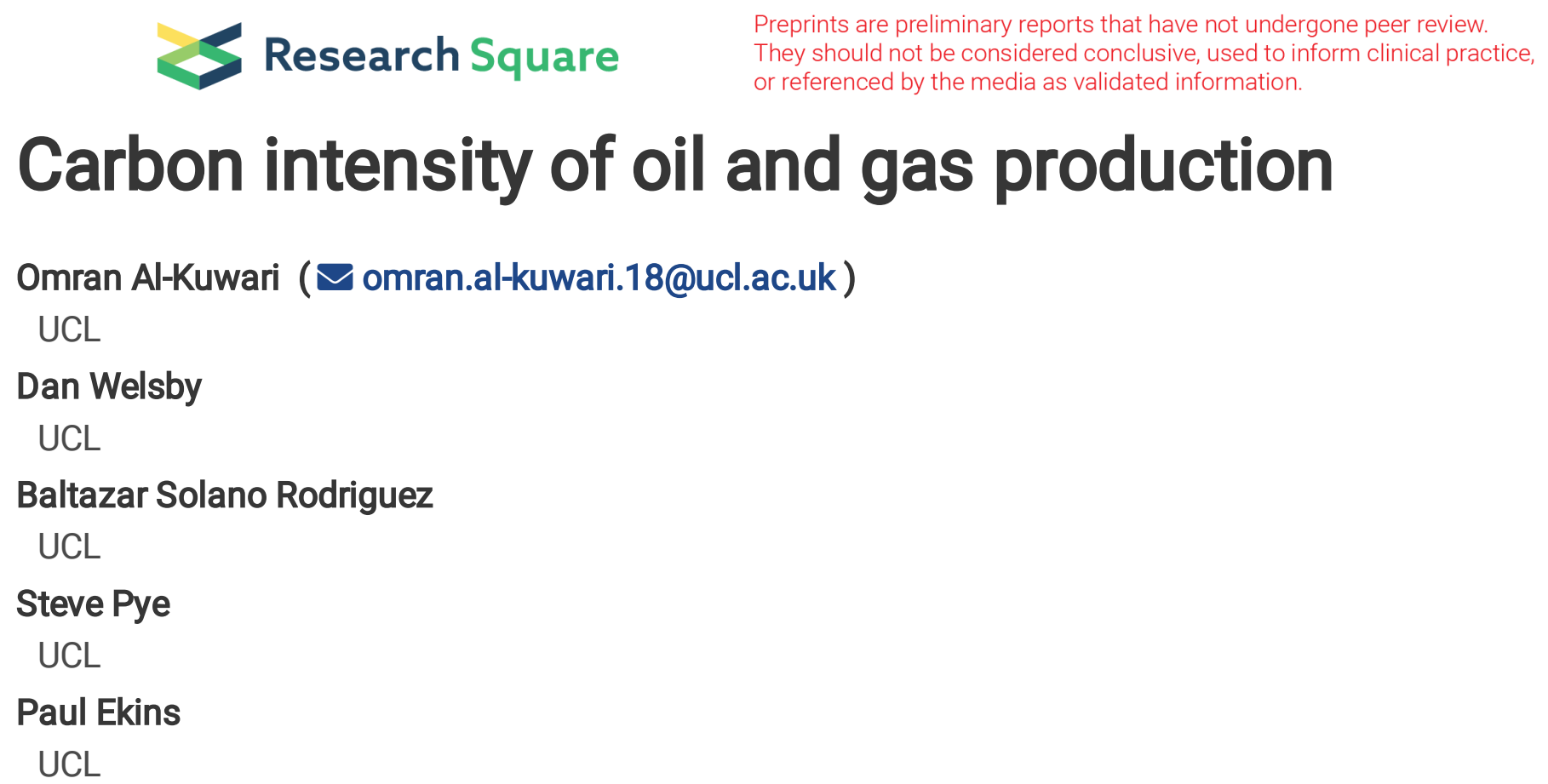

Keywords: oil and gas, carbon intensity, climate policy

Posted Date: June 22nd, 2021

DOl: https://doi.org/10.21203/rs.3.rs-637584/v1

License: (c) (1) This work is licensed under a Creative Commons Attribution 4.0 International License. Read Full License 


\section{Carbon intensity of oil and gas production}

Omran Al-Kuwari, Dan Welsby, Baltazar Solano Rodriguez, Steve Pye, Paul Ekins

June 2020 



\section{Executive summary}

This report focuses on reviewing the types of carbon intensity metrics, and the use of such metrics across the oil and gas sector, to monitor progress towards transitioning away from fossil fuel production. Producers are under pressure to respond to challenging conditions resulting from increasing climate policy, tightening markets and a move away by investors. A number of commentators are suggesting that production may have peaked, given these emerging trends, and the ongoing Covid-19 pandemic.

From a combination of review and modelling, this report provides some key insights on carbon intensity metrics and the impact of different carbon intensities on future production, which are pertinent to the future strategies of the oil and gas sector -

- Narrow-scoped metrics that only include upstream emissions are insufficient for producers reporting on progress towards climate goals. The carbon intensity of the final product also needs to be considered, given that it is increasingly subject to increased demand-side policy e.g. in relation to carbon pricing, bans on the sale of internal combustion engines (ICEs) etc.

- Given that climate targets are expressed in absolute terms, the relative measure of progress provided by carbon intensity metrics is insufficient to guide progress towards net-zero emissions. As shown by the modelling, there is a significant decline in the levels of production permitted under climate targets by 2050 .

- Given the need for diversification, metrics that account for scope 3 emissions will be important, to help monitor the transformation away from oil and gas. As discussed in this report, a number of IOCs appear to be making small steps in this direction, although their key business focus very much remains on oil \& gas. As the IEA (2020a) has reported, less than $1 \%$ of capital expenditure is being spent outside of core business areas.

- However, cleaner operations are also important. Therefore, scope $1 \& 2$ metrics are still useful for minimising upstream emissions. The modelling highlights the impact for example of high carbon intensity gas resources (due to methane emissions) on their production levels. Unconventional resources, which tend to require more energy input per unit of extraction, and are more costly, appear unlikely to be exploited in our Paris-aligned case.

- Any assertion that higher carbon intensity production upstream can be offset by lower emissions downstream (e.g. via higher vehicle efficiency standards) is not supported by the modelling. This is particularly the case where these oil products are 
exported abroad to regions with low efficiency forms of transportation/limited environmental regulation.

- National oil companies (NOCs) have more potential to achieve emission reduction from operational emissions, although the incentives to do so might be lower (with far less scrutiny and reporting). Diversification is also likely to be more of a challenge for NOCs, due to the reliance of public budgets on revenues gained. However, a number of high-producing countries are vigorously exploring diversification strategies. Such strategies could include massively increasing support for renewable industries, and focusing on areas such as hydrogen production and CCS applications.

- For the large NOC producers, with the lowest-cost conventional reserves, it is likely that they may be able to continue producing for the longest time, as climate policy stringency increases. However, given that NOCs hold the largest reserves, risks of stranding will be greater in absolute terms. 


\section{Contents}

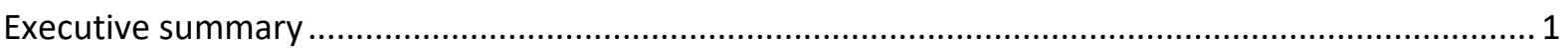

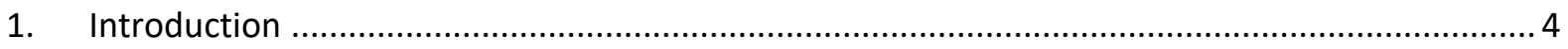

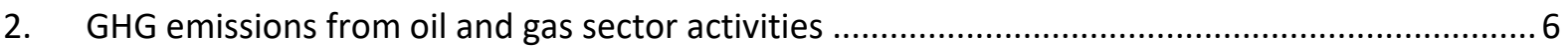

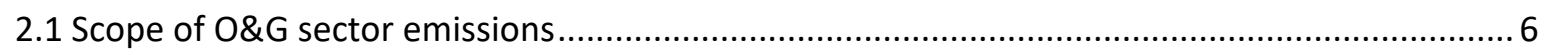

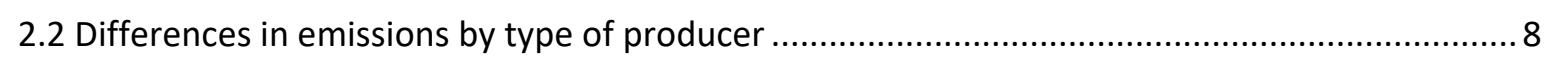

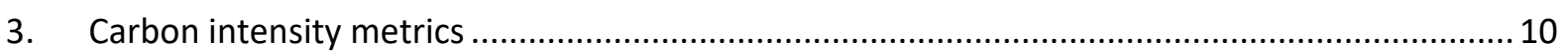

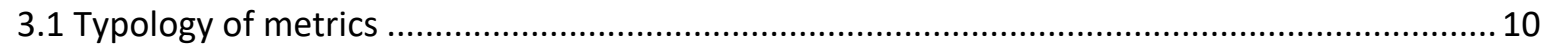

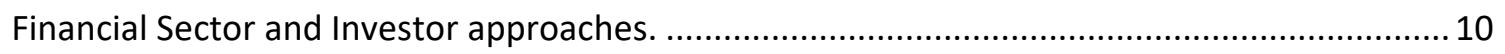

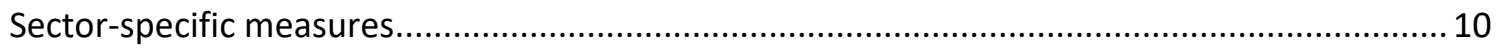

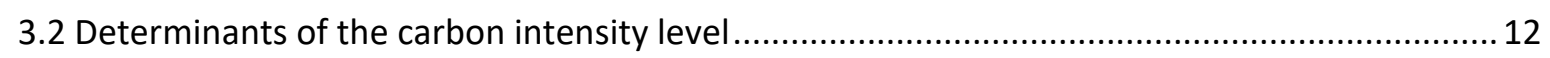

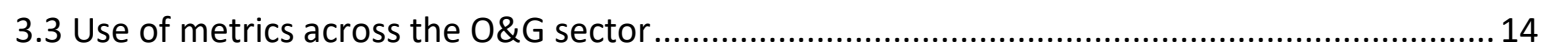

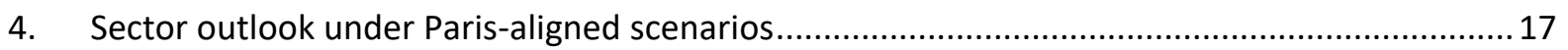

4.1 Field-/resource-level carbon intensity database .....................................................................17

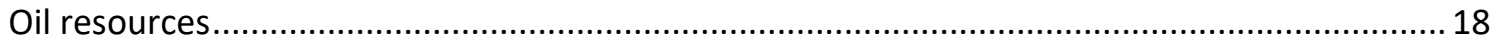

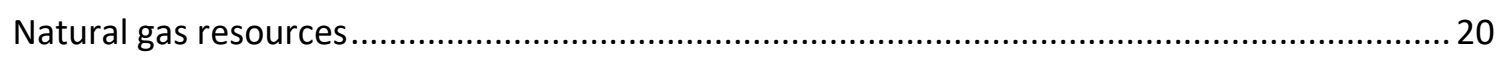

4.2 Implementation of carbon intensity metrics and mitigation measures in TIAM-UCL.................2 21

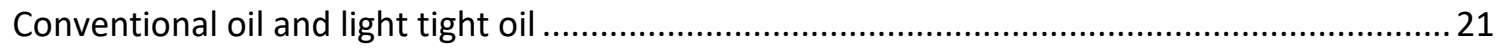

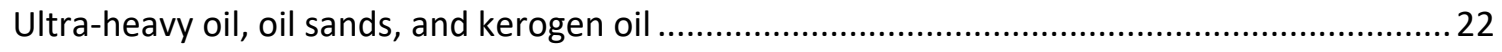

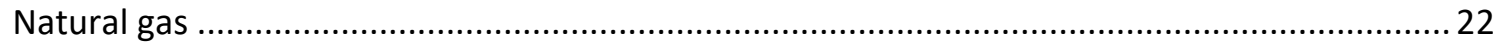

Mitigation options to reduce carbon intensity of production in TIAM-UCL ................................23

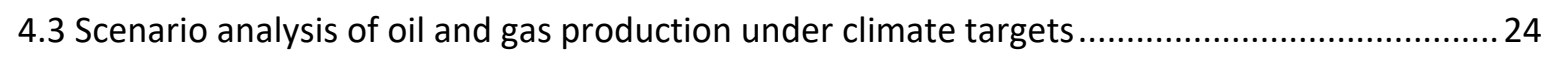

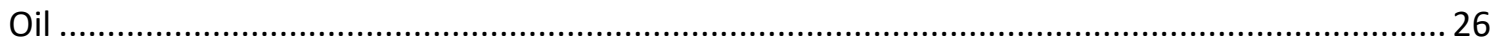

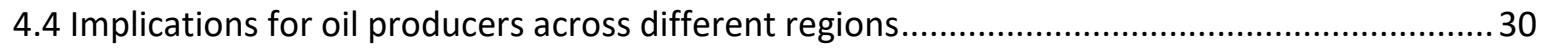

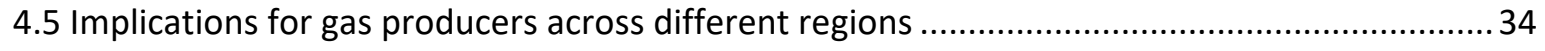

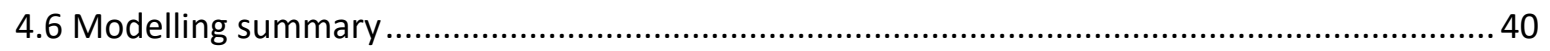

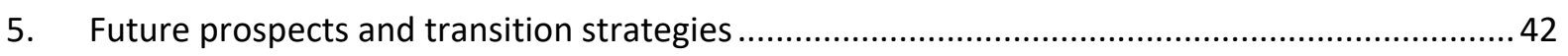

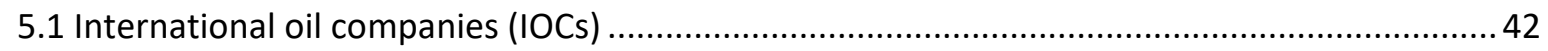

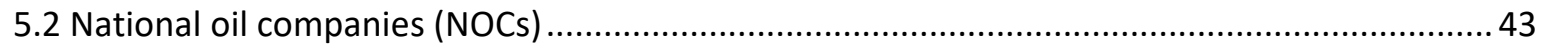

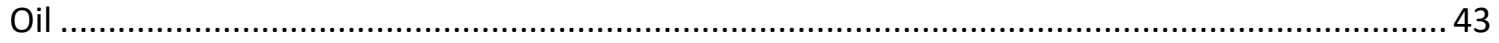

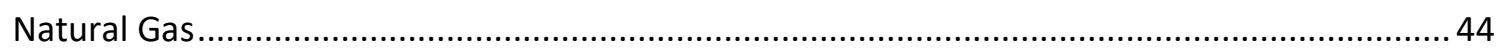

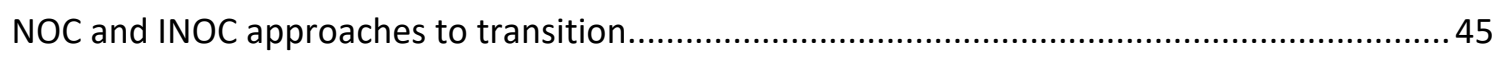

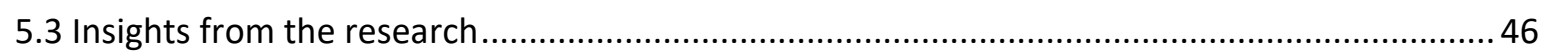

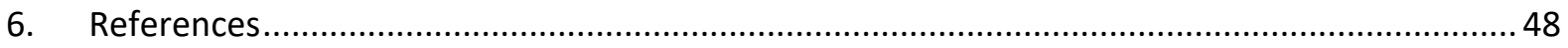




\section{Introduction}

The oil and gas sector is increasingly exposed to a range of factors that are hitting profitability, discouraging investment and raising questions about the future of the industry. While short term challenges of the Covid-19 pandemic are hitting the sector hard, long-term trends of falling renewable costs and increasing stringency of climate policy mean that the sector is being forced to redefine both purpose and how it operates.

The climate challenge was put in stark terms by research conducted by UCL's Institute for Sustainable Resources (McGlade \& Ekins, 2015), where limiting an average global temperature increase to $2^{\circ} \mathrm{C}$ implies that $33 \%$ of the world's oil, $50 \%$ of its gas and $80 \%$ of its coal reserves would remain unused in 2050 . Therefore the trend in extraction has to change; if it continues over the next 30 years as it has over the previous 3 decades, then global average temperatures would be on course to rise around $4^{\circ} \mathrm{C}$ above pre-industrial levels by the end of the century (Griffin, 2017). The Production Gap report (SEI et al., 2019) recently highlighted how the plans of producers were strongly misaligned with the Paris Agreement goals, with countries planning to produce about $50 \%$ and $120 \%$ more fossil fuels by 2030 than would be consistent with a $2^{\circ} \mathrm{C}$ and $1.5^{\circ} \mathrm{C}$ pathway respectively.

The reduction in costs in new energy technologies (BNEF, 2019), increasing policy responses by governments, and changing perspectives of investors, highlight the need for the oil and gas sector to change. Concerning policy, 57 carbon pricing programs exist in 46 countries, meaning that $20 \%$ of global GHGs will be covered by carbon-pricing schemes (Naimoli, Stephen, \&Ladislaw, 2019). Concerning investment, fossil fuel divestment is reported to be the fastest growing divestment movement in history (Renew Economy, 2019). 182 shareholder resolutions concerning climate change were introduced at oil \& gas companies from 2015 to 2018 (Naimoli, Stephen, \&Ladislaw, 2019). These trends are likely to increase, as the negative effects of climate change become increasingly apparent, introducing serious business risk for companies involved in investment in exploration for or production of fossil fuels, as well as for fossil fuel producers themselves.

One approach to thinking about the 'climate performance' of the sector has been the use of carbon intensity metrics. Such metrics can provide information on the impact of oil companies in terms of carbon emitted relative to output, and help monitor progress over time. In this report, we consider the following issues relevant to the use of carbon intensity metrics -

i. Source of GHG emissions across the oil and gas value chain (including upstream, transport and refining, end use (or downstream))

ii. Carbon intensity of activities across the value chain

iii. Options for reducing carbon intensity

iv. The range of metrics used to estimate carbon intensity (i.e. how carbon intensity is defined), and their purpose

v. The strengths and weaknesses of different carbon intensity metric in view of climate goals

vi. Alignment of carbon intensity metrics with ambition under the Paris Agreement 
To address these issues, the report is structured as follows: section 2 first provides an overview of the emissions associated with the oil and gas sector, and how these are attributed based on different scope definitions (points i and ii above). Section 3 describes the different carbon intensity metrics that are being used to monitor the GHG footprint of different activities in the oil and gas sector, why they vary and how they are being applied by producers (points iii, iv and v). Section 4 undertakes a modelling exercise, using the global energy system model TIAM-UCL, to explore the impact of the carbon intensity of production on the use of oil and gas resources in the future, as the energy sector transitions to a lowcarbon system (point vi). Section 5 considers the strategies currently being undertaken by different producers, reflecting on the insights from the modelling work. 


\section{GHG emissions from oil and gas sector activities}

Global GHG emissions were approximately $53 \mathrm{GtCO}_{2} \mathrm{e}$ in 2017 (IPCC, 2018). According to the Intergovernmental Panel on Climate Change (IPCC, 2018), global $\mathrm{CO}_{2}$ emissions must be $25 \%$ to $55 \%$ lower than 2017 in 2030 to steer the world to the least-cost pathway to limit average global warming to $2^{\circ} \mathrm{C}$ and $1.5^{\circ} \mathrm{C}$ respectively.

Global energy-related $\mathrm{CO}_{2}$ emissions were at $33 \mathrm{Gt} \mathrm{CO}_{2}$ in 2019 (IEA, 2020b), representing $66 \%$ of all GHG emissions, with oil \& gas consumption representing $40 \%$ and coal accounting for $26 \%$. This represents no increase on 2018 levels, which were preceded by two years of growth (2017-2018) after a three-year period of stabilisation from 2014 to 2016 (IEA, 2020b). Future years remain highly uncertain, notably 2020 and 2021 due to the impact of the Covid-19 pandemic. Current estimates suggest 2020 emissions will decline by $8 \%$ compared to the previous year, down to $30.6 \mathrm{GtCO}_{2}$ (IEA, 2020c).

\subsection{Scope of O\&G sector emissions}

A key question concerns attribution of emissions to fossil fuel producers, based on where the boundary of responsibility lies. This is important for understanding the strategy of the sector as a whole in a decarbonising world, and that of different companies. Therefore, when analysing or comparing emissions data related to the fossil energy industry, it is important to clearly define what the boundaries are of the different sectors. This is particularly important for the production and consumption of oil \& gas and coal, with the vast majority of emissions taking place when these energy commodities are used in end use sectors (as discussed above).

In this respect, the fossil fuel industry, including oil and gas, is completely different from other industry sectors: the environmental impact of most industries derives from their production processes, not the use of their products; for the fossil fuel industry, over threequarters of its impact on global warming occurs when its products are burned. ${ }^{1}$ Similar to the production vs consumption debate, oil $\&$ gas companies are under pressure to focus beyond direct operational emissions (Carbon Tracker, 2019; Dupré et al., 2015 ).

For the energy sector, there is a standard classification used for thinking about the scope of GHG emissions associated with oil and gas (O\&G) sector emissions, based on the following definitions -

- Scope 1 - direct, operational emissions based on company facilities and vehicles; methane management and increased efficiency; emissions arising from the selfconsumption of fuel, flaring, and venting or fugitive releases of methane

\footnotetext{
${ }^{1}$ For example, based on the Carbon Majors Database (Griffin, 2017), it is estimated that 90 carbon producers have historically contributed to approximately $57 \%$ of the observed rise in $\mathrm{CO}_{2}, 42-50 \%$ of the rise in global mean surface temperature (GMST) and $26-32 \%$ of global sea level (GSL). For 2019, they would be responsible for $66 \%$ of all GHG emissions.
} 
- Scope 2-emissions imported from heat and electricity (i.e. accounting for carbon intensity of heat and electricity supplied)

- Scope 3 - indirect emissions, ranging from embedded emissions in the supply chain to the use and end-of-life processing (e.g. consumers driving cars using fuels produced by $O \& G$ company; emissions from energy used to manufacture $O \& G$ equipment).

The coverage implied by these definitions is illustrated in Figure 1.

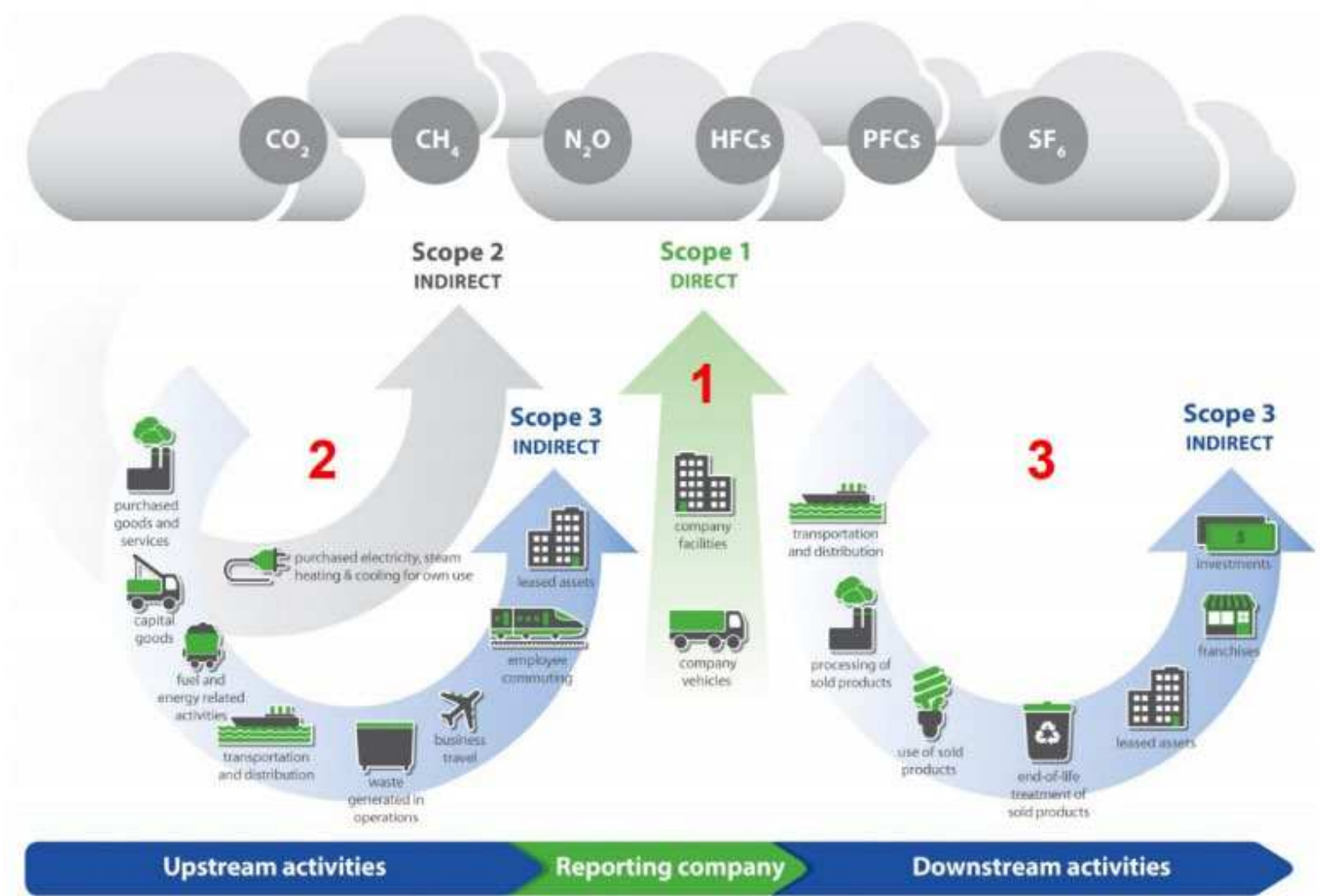

Figure 1. Illustration of different emission reporting scopes (Watterson, 2014)

As can be seen in the lower bar of Figure 2, scope 3 emissions (grey shaded area) that are mainly driven by the use of oil and gas products, account for some $90 \%$ of total emissions associated with the production and use of oil and gas. The difference between oil and gas production emissions and scope $1 \& 2$ emissions (comparing the blue areas of the lower two bars) is that production also includes extraction, processing and transportation of oil \& gas. 


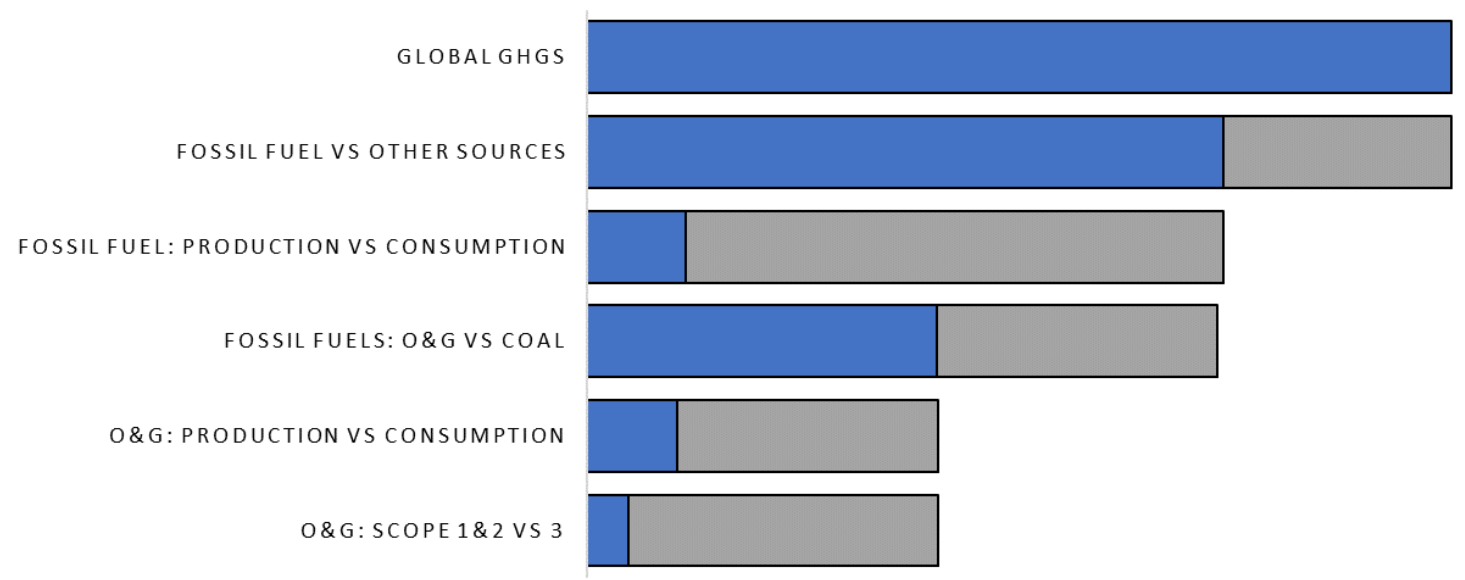

Figure 2. Illustrative estimates of oil and gas sector emissions, compared to total GHGs $\sim 53 \mathrm{GtCO}_{2} \mathrm{e}($ (Source: Authors own estimates based on range of sources)

To get to net-zero emissions over the full life cycle of production and consumption (when including scope 3), the fossil fuel industry will effectively have to completely diversify away from its core business, with the exception that fossil fuels may be able to be used in CCS technologies; however, it is highly uncertain whether such technologies will be available at scale. Markets for fossil fuel products that are much more dispersed, including buildings and transport would see no opportunity for use of oil and gas. The only other strategy is to use offsets over a time-limited period (due to the need to get to zero emissions across all sectors by 2050) through the purchase of emission credits - but such an approach is also beset by numerous problems.

\subsection{Differences in emissions by type of producer}

While Figure 2 shows the global average share of scope $1 \& 2$ and scope 3 emission, those numbers vary significantly across different types of oil and gas companies. This is shown in Figure 3, with much higher shares of scope $1 \& 2$ emissions from National Oil Companies (NOCS). Conversely the larger International Oil Companies (IOCs), or Majors, and INOCs (NOCs operating beyond their own borders) tend to have lower emissions for scope $1 \& 2$. As discussed in the section that follows, the emissions associated with different operations will be determined by a range of factors, including company practices, and the types of resources being extracted. 


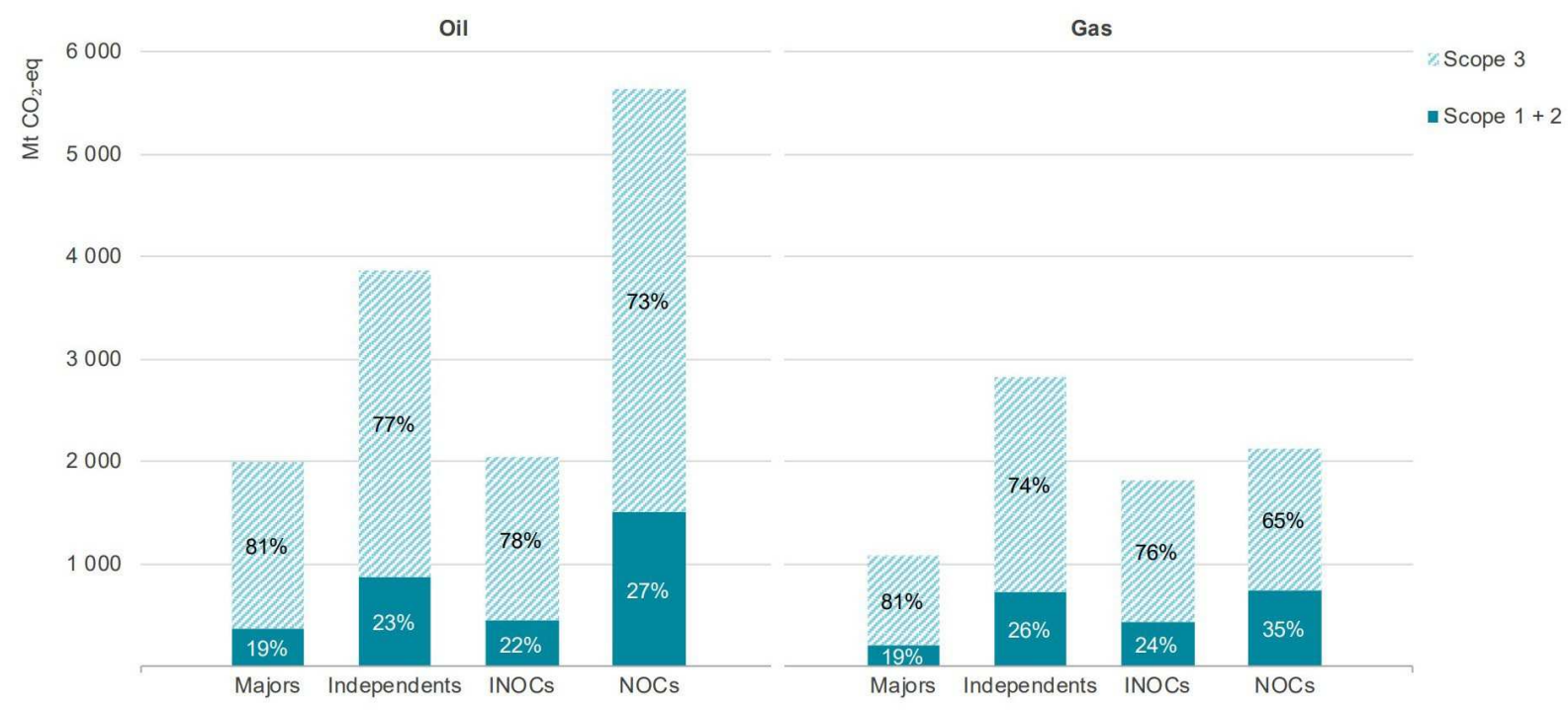

Figure 3. Difference in emission scope by type of oil producer (Source: IEA, 2020a) 


\section{Carbon intensity metrics}

Carbon Intensity $(\mathrm{Cl})$ refers to the amount of greenhouse gas emitted per unit of activity. The definition of $\mathrm{Cl}$ can differ in scope depending on the purpose of the metric. For instance, the Oil \& Gas Climate Initiative, an industry-led group, bounds carbon intensity to the volume of carbon dioxide and methane emissions per unit of production of oil \& gas. $\mathrm{Cl}$ metrics are gaining popularity in the energy industry as a metric as it allows companies to improve their performance by increasing the denominator of the ratio (e.g. by adding levels of low-carbon sources in equivalent energy units, such as through wind or solar projects), without necessarily reducing their absolute emissions (the numerator) from the rest of their energy production. This has led to criticism of $\mathrm{Cl}$ in the context of net zero emissions ambition, because focusing on $\mathrm{Cl}$ rather than reducing overall absolute emissions means that companies can achieve a reduction in their respective intensity metrics without reducing emissions in their production, and therefore never reach net zero targets.

In addition to adding low or zero carbon sources to a portfolio, $\mathrm{Cl}$ can be mitigated by investing in operational improvements and technology focused on energy efficiency measures, managing fugitive methane leaks, capturing $\mathrm{CO}_{2}$ streams through carbon capture and eliminating flaring with natural gas valorisation processes. While these actions can never reduce more than a quarter of life cycle emissions from the sector, as they only cover scope $1 \& 2$, the reductions they can achieve are by no means insignificant (as highlighted in Figure 3).

\subsection{Typology of metrics}

A range of different measures and metrics have been developed for a variety of climaterelated objectives (UNEP, 2015).

Financial Sector and Investor approaches.

"Carbon risks" is one category of metrics which addresses risks in business, which assess financial risks and opportunities of portfolios driven by changes in climate policies, technology and corporate decisions. "Climate friendliness" is another category, designed to assess the overall contribution of a business to GHG emissions and the low-carbon economy transition (UNEP, 2015). These measures use a range of metrics to inform narrower measures used in sector or by analysts for assessing carbon emissions.

\section{Sector-specific measures}

Carbon foot-printing and carbon metrics provide cross-sector assessments of a portfolio's exposure to GHG emissions, which connects between climate change and portfolios. Examples include the Carbon Disclosure Project's (CDP) Carbon Majors approach which provides sectoral guidance for companies to inform GHG emissions trajectories needed to converge to meet climate goals. Similarly, the Global Reporting Initiative (GRI) provides a set of sustainability reporting guidelines on economic, environmental and social impacts. Green / brown metrics provide sector-specific indicators that distinguish between activities and technologies that are climate solutions and climate problems. They lay out positive or negative screenings for project finance with quantitative data. Examples include the 
Stockholm Environment Institute's (SEI) metric which provides guidance on the alignment of financial assets with 2 degree scenarios, and Carbon Tracker's analysis on investment projects that would be stranded under various scenarios. Table 1 describes some of these metrics in more detail.

Table 1. Comparison of types of carbon intensity metrics

\begin{tabular}{|c|c|c|c|}
\hline Metric & Scope & Description & Comments \\
\hline \multicolumn{4}{|c|}{ FINANCIAL SECTOR AND INVESTOR APPROACHES } \\
\hline $\begin{array}{l}\text { “Carbon Risks" } \\
\text { (UNEP, 2015) }\end{array}$ & $\begin{array}{l}\text { Assess business risk, } \\
\text { including financial risks } \\
\text { and opportunities of } \\
\text { portfolios driven by } \\
\text { changes in climate } \\
\text { policies, technology } \\
\text { and corporate decisions }\end{array}$ & $\begin{array}{l}\text { - Company's upstream } \\
\text { flaring intensity } \\
\text { - Carbon footprint vs } \\
\text { non-oil net asset value } \\
\text { exposure } \\
\text { - Company portfolio } \\
\text { changes } \\
\text { - Emission reduction } \\
\text { trajectory vs various } \\
\text { climate scenarios (ie. } \\
\text { 2DS) }\end{array}$ & $\begin{array}{l}\text { - JP Morgan and Goldman } \\
\text { Sachs have presented some } \\
\text { of the indicators } \\
\text { Transition Pathway Initiative } \\
\text { (TPI) focuses on } \\
\text { management quality, carbon } \\
\text { performance and } \\
\text { transparency of data }\end{array}$ \\
\hline $\begin{array}{l}\text { "Climate Friendly" } \\
\text { (UNEP, 2015) }\end{array}$ & $\begin{array}{l}\text { - Intent of an investor to } \\
\text { contribute to GHG } \\
\text { emissions reductions } \\
\text { and the transition to a } \\
\text { low-carbon economy } \\
\text { through investment } \\
\text { activities (UNEP, 2015) } \\
\text { Assess the overall } \\
\text { contribution to GHG } \\
\text { emissions and the low- } \\
\text { carbon economy } \\
\text { transition }\end{array}$ & $\begin{array}{l}\text { Carbon Footprint - } \\
\text { cross-sector portfolio } \\
\text { level assessment of } \\
\text { exposure to GHG } \\
\text { emissions } \\
\text { Green/Brown Metrics - } \\
\text { sector-specific } \\
\text { indicators distinguishing } \\
\text { between climate } \\
\text { solutions (green) and } \\
\text { climate problems } \\
\text { (brown); negative / } \\
\text { positive screening for } \\
\text { projects. } \\
\text { Climate ESG Scores - } \\
\text { analysis of climate } \\
\text { strategies, including } \\
\text { investments in low- } \\
\text { carbon projects/ } \\
\text { technologies }\end{array}$ & $\begin{array}{l}\text { - Carbon footprint - most } \\
\text { commonly used metric; over } \\
5,000 \text { companies in } 2014 \\
\text { reported to CDP using } \\
\text { mostly the GHG Protocol } \\
\text { approach. } \\
\text { - For Oil \& Gas (ie Carbon } \\
\text { Tracker) } \\
\quad \text { Green metrics - share } \\
\quad \text { of carbon capture, } \\
\quad \text { R\&D, renewables } \\
\text { Brown metrics - share of } \\
\text { high-cost capital } \\
\text { expenditure, } \\
\text { unconventional oil in } \\
\text { production mix (i.e. oil } \\
\text { sands, deep water) }\end{array}$ \\
\hline \multicolumn{4}{|c|}{ SECTOR SPECIFIC MEASURES } \\
\hline $\begin{array}{l}\mathrm{Cl} \text { w/Direct GHG } \\
\text { Emissions }\end{array}$ & $\begin{array}{l}\text { - Covers production } \\
\text { and/or "upstream" } \\
\text { - Defined as scope } 1 \text { and } \\
2\end{array}$ & $\begin{array}{ll}\text { - } & \text { Easier to measure } \\
\text { - } & \text { Absolute or intensity \% } \\
\text { number }\end{array}$ & $\begin{array}{l}\text { - Focused on reducing gas } \\
\text { emissions from its oil and } \\
\text { gas fields } \\
\text { - Preferred metric by Oil \& } \\
\text { Gas industry "under their } \\
\text { control" } \\
\text { Does not cover a significant } \\
\text { portion of the chain (up to } \\
90 \%)\end{array}$ \\
\hline $\begin{array}{l}\mathrm{Cl} \text { w/Indirect } \\
\text { Emissions }\end{array}$ & $\begin{array}{l}\text { - Covers embedded } \\
\text { emissions from the } \\
\text { supply chain to the use } \\
\text { and end-of-life } \\
\text { processing } \\
\text { Defined as Scope } 3\end{array}$ & $\begin{array}{l}\text { - } \quad \text { Difficult to measure } \\
\text { - Provides assessment of } \\
\text { overall energy } \\
\text { production } \\
\text { - } \begin{array}{l}\text { Absolute or intensity \% } \\
\text { number }\end{array}\end{array}$ & $\begin{array}{l}\text { Requires companies } \\
\text { themselves to reduce the } \\
\text { carbon intensity of the } \\
\text { products they sell } \\
\text { - Strong resistance from Oil \& } \\
\text { Gas companies }\end{array}$ \\
\hline $\begin{array}{l}\text { Shell's Net carbon } \\
\text { footprint }\end{array}$ & $\begin{array}{l}\text { - Shell has developed a } \\
\text { lifecycle emissions } \\
\text { metric to track its } \\
\text { progress. }\end{array}$ & $\begin{array}{l}\text { Differs in that it is not a } \\
\text { mathematical } \\
\text { derivation of total } \\
\text { emissions divided by }\end{array}$ & $\begin{array}{l}\text { Indicates that use of sold } \\
\text { products accounts for } 86 \% \\
\text { of its value-chain or Scope } 3\end{array}$ \\
\hline
\end{tabular}




\begin{tabular}{|c|c|c|c|}
\hline & $\begin{array}{l}\text { Net carbon footprint is } \\
\text { presented in units of } \\
\text { Well to Wheels (WTW) } \\
\text { grams of CO2 } \\
\text { equivalent emissions } \\
\text { per MJ of energy. }\end{array}$ & $\begin{array}{l}\text { total energy, but a } \\
\text { weighted average } \\
\text { aggregation of lifecycle } \\
\text { carbon intensities of } \\
\text { different energy } \\
\text { products normalised to } \\
\text { the same point relative } \\
\text { to final end-use. } \\
\text { - } \quad \text { Bespoke solution } \\
\text { - Not industry standard } \\
\text { - Highly aggregated }\end{array}$ & $\begin{array}{l}\text { emissions and } 77 \% \text { of all its } \\
\text { emissions in } 2017 \\
\text { Shell was the first oil and gas } \\
\text { company to include } \\
\text { emissions associated with } \\
\text { the use of the energy } \\
\text { products that they sell in } \\
\text { plans related to climate } \\
\text { change } \\
\text { Non-energy products such } \\
\text { as chemicals, lubricants and } \\
\text { bitumen are not included } \\
\text { since their end-use is not } \\
\text { linked to combustion. }\end{array}$ \\
\hline $\begin{array}{l}\text { Life Cycle Analysis } \\
\text { (LCA) }\end{array}$ & $\begin{array}{l}\text { Assesses multiple } \\
\text { environmental impact } \\
\text { categories, includes } \\
\text { global warming, human } \\
\text { health impacts, } \\
\text { ecosystem quality, } \\
\text { acidification, land use, } \\
\text { etc } \\
\text { Includes emissions due } \\
\text { to the production and } \\
\text { end-of-life of materials, } \\
\text { plants and machineries } \\
\text { used for processes. }\end{array}$ & $\begin{array}{l}\text { - Complex and expensive } \\
\text { method, requiring a big } \\
\text { set of variables } \\
\text { No clear link of oil \& gas } \\
\text { to climate impact }\end{array}$ & $\begin{array}{l}\text { - Useful for a company to } \\
\text { track carbon footprint of } \\
\text { specific products and } \\
\text { services. } \\
\text { Well to Wheels - specific LCA } \\
\text { used for transport fuels and } \\
\text { vehicles }\end{array}$ \\
\hline
\end{tabular}

Source: Authors

\subsection{Determinants of the carbon intensity level}

Carbon intensity as it relates to scope $1 \& 2$ can be used to reflect heterogeneity across a range of parameters which impact the level of carbon (and other GHG) emissions per unit of oil/gas production. The main drivers of varying carbon intensity, which impact the amount of fuel needed for extraction, the distance to transport the fuel, the amount of leakage, and potential flaring among other considerations include:

- Geology of the oil/gas deposits

- Geographical location of the oil/gas deposits

- Maturation of both the oil/gas field and the technology being utilised

- Regulatory regimes and environmental practice stringency

These drivers can be heavily interlinked; for example, if an isolated oil field (e.g. offshore) is under operation in a country with limited regulation of flaring practices, it is highly likely that any associated gas will be burnt off or even vented directly into the atmosphere, given limited financial incentive to utilise the gas by piping it to shore, and limited risk of penalties for carbon-intensive flaring / methane-intensive venting.

Carbon intensity is determined by a range of different sources across the production process. Extraction, processing and transporting of oil \& gas to end users represents approximately $20 \%$ of full life cycle emissions of oil and $25 \%$ of full life cycle emissions of gas (as shown in the 'O\&G: Production vs Consumption' bar of Figure 2). The breakdown by 
source for emissions in 2017 is shown in Table 2, with oil resulting in nearly $50 \%$ more indirect GHG emissions than gas, collectively representing $5.2 \mathrm{Gt} \mathrm{CO}_{2} \mathrm{e}$. Methane emissions are particularly important in the gas value chain.

Table 2. Contribution of different sources to global emissions from oil and gas extraction, processing and transportation in 2017 (Source: IEA, 2018b)

\begin{tabular}{|c|c|c|}
\hline Value chain & Emission source & $\begin{array}{l}\text { Emission level } \\
\left(\mathrm{GtCO}_{2} \mathrm{e}\right)\end{array}$ \\
\hline \multirow[t]{6}{*}{ Oil } & Energy for extraction & 0.39 \\
\hline & Flaring & 0.27 \\
\hline & Refining & 1.11 \\
\hline & Transport & 0.29 \\
\hline & Methane & 1.08 \\
\hline & Total & 3.14 \\
\hline \multirow[t]{6}{*}{ Gas } & Energy for extraction & 0.54 \\
\hline & Venting $\mathrm{CO} 2$ & 0.15 \\
\hline & Transport & 0.12 \\
\hline & Methane - upstream & 0.86 \\
\hline & Methane - downstream & 0.43 \\
\hline & Total & 2.1 \\
\hline
\end{tabular}

There is a wide distribution in the GHG intensity of different types and sources of oil \& gas from around the world (Figure 4). For gas, the primary driver of this variation is the methane emissions associated with production. For oil, again methane plays an important role in driving differences, but refining and energy inputs are also important. This variation and the implications for the production of different resources is explored in more detail in section 4 of this report.

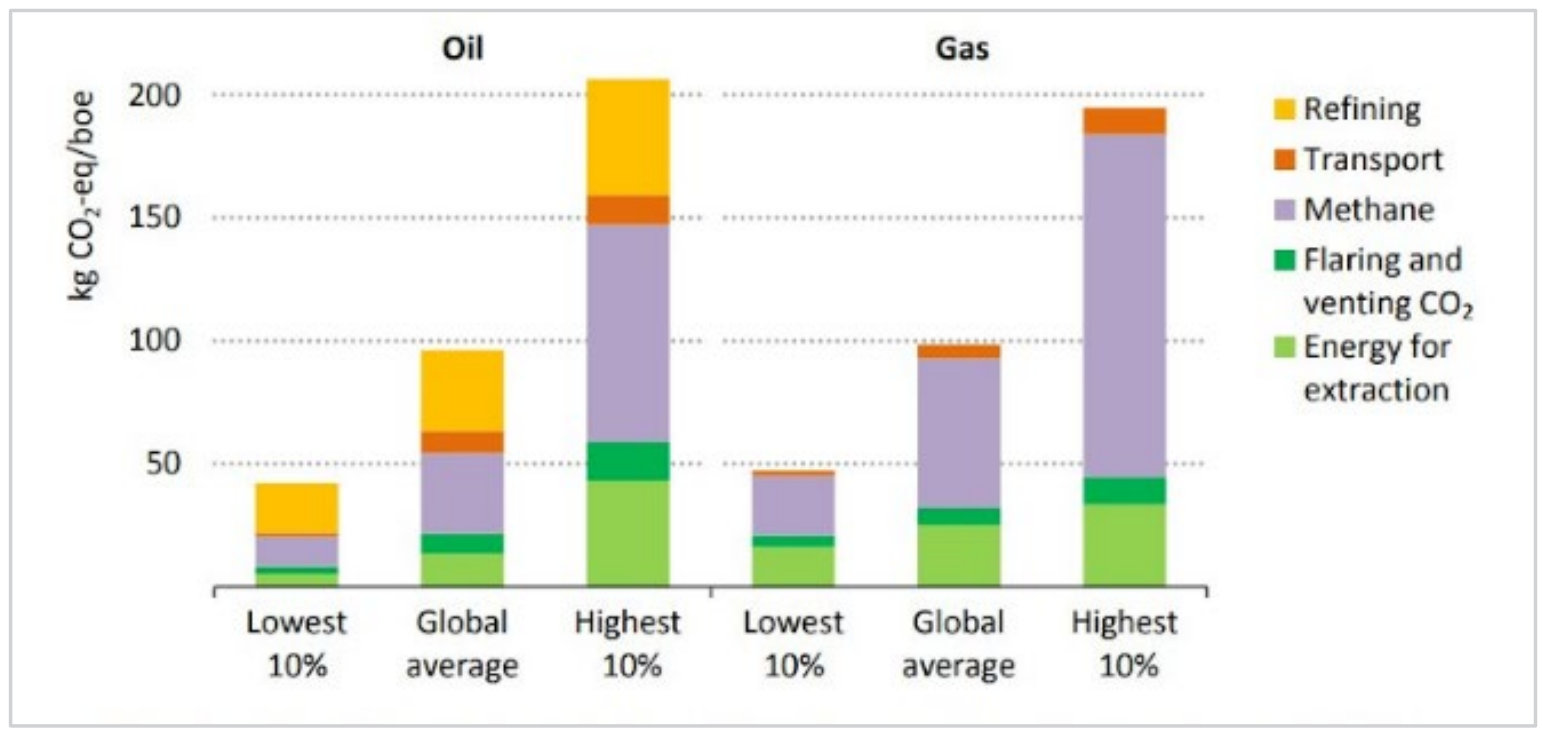

Figure 4. Variation in the carbon intensity of oil and gas production by source (Source: IEA, 2018b)

According to the Transition Pathway Initiative (TPI), between 2015 and 2017, the current average carbon intensity of the largest oil and gas companies is tightly clustered between 68 $\mathrm{gCO}_{2} / \mathrm{MJ}$ and $82 \mathrm{gCO}_{2} / \mathrm{MJ}$ for scope $1 \& 2$ plus scope 3 emissions from the use of sold 
products. There are broadly four factors that explain the company differences within this range: the proportion of natural gas in the mix, variation in the emissions intensity of liquid products, the extent of downstream activity, and the level of operational emissions. The variation in carbon intensity across different oil and gas resources is considered further in the modelling, described in section 4.

\subsection{Use of metrics across the O\&G sector}

The oil \& gas industry has strongly resisted being "responsible" for emissions that are not in their direct control, and have continuously pushed to focus on improving emissions from the production process. The International Petroleum Industry Environmental Conservation Association (IPIECA) argues that most of the potential for savings lies with end-users and that the industry's focus should be on efficiently reducing emissions in its own operations (scope 1\&2). The Oil \& Gas Climate Initiative (OGCI), which represents $32 \%$ of global production and $1.3 \%$ of global GHG emissions, focuses on emissions from production only, specifically from exploration, direct operations, LNG liquefaction and imports of electricity and steam (also scope $1 \& 2$ ).

Of the major International Oil Companies (IOCs), Shell, BP, Total, and ENI have stated longterm emissions and carbon intensity targets. They have expressed ambitions to reduce both operational emissions and emissions in their value chains, including from the use of sold products to align with Paris pledges. The different approaches taken by major oil companies are set out in Table 3.

NOCs do not have the same pressures to disclose climate related targets since they are less prone to dealing with public and investment pressure. However, it can be expected that this will change with time as some companies will require access to capital for new projects and will have to respond to other stakeholders and constituents by laying out energy transition strategies (more on NOC dynamics in section 5 below). 
Table 3. Approaches to the use of $\mathrm{Cl}$ metrics and targets across the oil \& gas majors

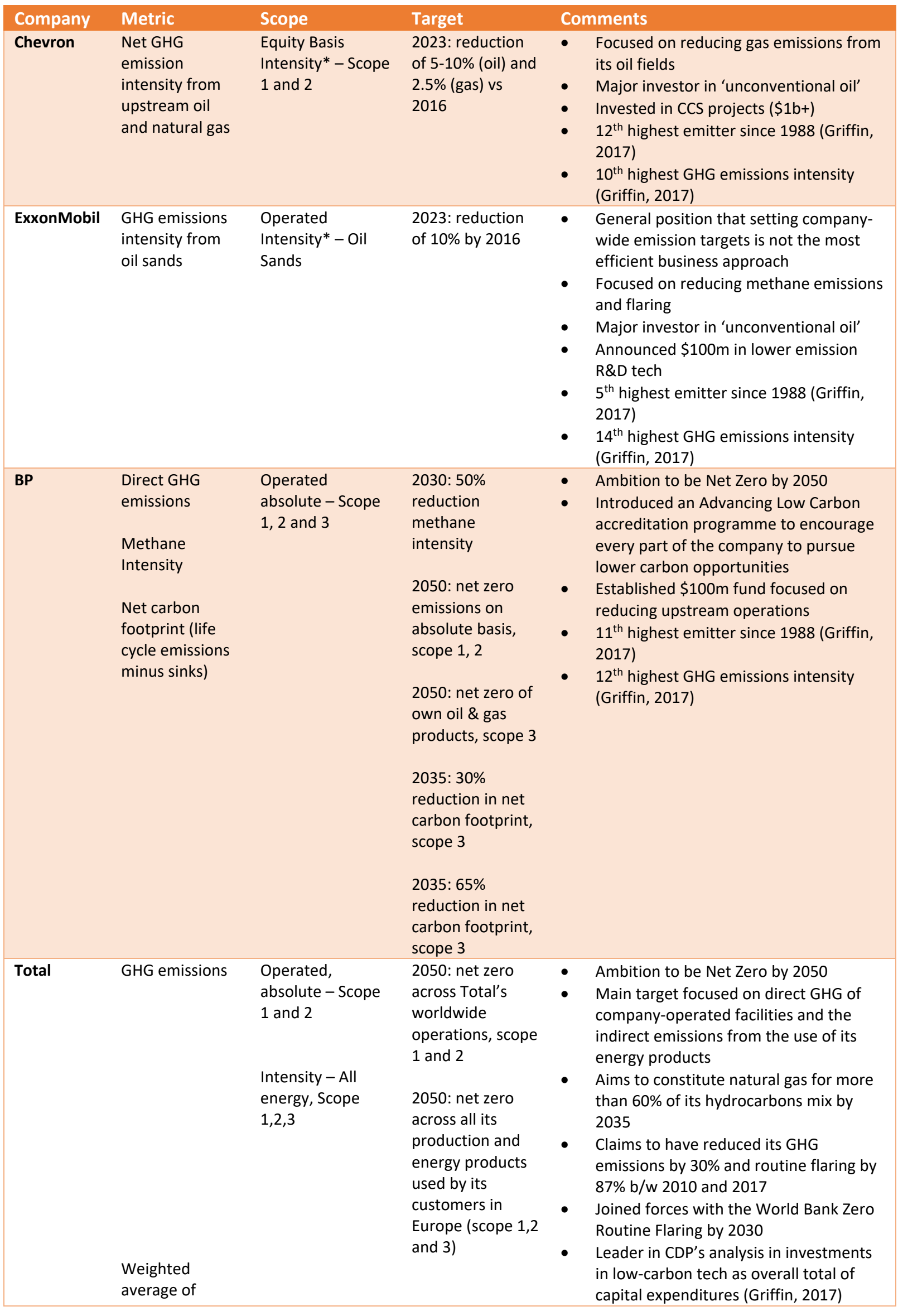




\begin{tabular}{|c|c|c|c|c|}
\hline & $\begin{array}{l}\text { lifecycle } \\
\text { emissions of } \\
\text { energy products } \\
\text { sold }\end{array}$ & & $\begin{array}{l}2050: 60 \% \text { or } \\
\text { more reduction in } \\
\text { the average } \\
\text { carbon intensity } \\
\text { of energy } \\
\text { products used } \\
\text { worldwide } \\
\text { customers }\end{array}$ & $\begin{array}{l}\text { - } 19^{\text {th }} \text { highest emitter since } 1988 \text { (Griffin, } \\
2017 \text { ) } \\
17^{\text {th }} \text { highest GHG emissions intensity } \\
\text { (Griffin, 2017) } \\
\text { - Allocates more than } 10 \% \text { of its Capex to } \\
\text { low-carbon electricity, the highest level } \\
\text { among the Majors }\end{array}$ \\
\hline Shell & $\begin{array}{l}\text { Direct GHG } \\
\text { emissions } \\
\text { Methane } \\
\text { intensity } \\
\text { Net carbon } \\
\text { footprint }\end{array}$ & $\begin{array}{l}\text { Equity Basis } \\
\text { Intensity - All } \\
\text { energy } \\
\text { Scope 1, 2, } 3\end{array}$ & $\begin{array}{l}\text { 2025: methane } \\
\text { intensity below } \\
0.2 \% \\
2050 \text { : net zero } \\
\text { emissions (Scope } \\
\text { 1,2, and 3) } \\
2050 \text { : reduce } \\
\text { carbon intensity } \\
\text { of its products by } \\
65 \% \text {. }\end{array}$ & $\begin{array}{l}\text { - Ambition to be Net Zero by } 2050 \\
\text { Before committing to the net-zero } \\
\text { target, the Dutch-Anglo giant was one of } \\
\text { the fastest-moving companies in the } \\
\text { sector to commit to disclosing } \\
\text { emissions - not just from its own } \\
\text { operations, but from those produced by } \\
\text { its customers } \\
\text { - First oil and gas company to include } \\
\text { emissions associated with the use of the } \\
\text { energy products that they sell in plans } \\
\text { related to climate change } \\
\text { Target relies on the oil and gas company } \\
\text { shifting its business towards selling clean } \\
\text { energy products such as renewable } \\
\text { energy and biofuels, and working } \\
\text { alongside its "net-zero" customers to } \\
\text { also help offset the carbon impact too. } \\
\text { Intends to link the greenhouse gas } \\
\text { emissions and other measures to the } \\
\text { remuneration of its executives } \\
\text { gth highest emitter since } 1988 \text { (Griffin, } \\
2017 \text { ) } \\
21^{\text {st }} \text { highest GHG emissions intensity } \\
\text { (Griffin, 2017) }\end{array}$ \\
\hline ENI & $\begin{array}{l}\text { Direct GHG } \\
\text { emissions } \\
\text { Lifecycle carbon } \\
\text { emissions per } \\
\text { unit of energy } \\
\text { products sold } \\
\text { Carbon intensity } \\
\text { of energy } \\
\text { production }\end{array}$ & $\begin{array}{l}\text { Absolute } \\
\text { emissions - scope } \\
1,2,3 \\
\text { Relative net } \\
\text { carbon intensity } \\
\text { of energy } \\
\text { production - } \\
\text { scope } 1,2 \text { and } 3\end{array}$ & $\begin{array}{l}\text { 2035: reduce } \\
\text { absolute net } \\
\text { lifecycle } \\
\text { emissions by } 30 \% \\
\text { (scope } 1,2,3 \text { vs } \\
\text { 2018) } \\
\text { 2035: reduce net } \\
\text { carbon intensity } \\
\text { of energy } \\
\text { production by } \\
\text { 15\% (scope 1, 2, } 3 \\
\text { vs } 2018 \text { ) } \\
2050 \text { : reduce } \\
\text { absolute net } \\
\text { lifecycle } \\
\text { emissions by } 80 \% \\
\text { (scope } 1,2,3 \text { vs } \\
2018 \text { ) } \\
2050 \text { : reduce net } \\
\text { carbon intensity } \\
\text { of energy } \\
\text { production by } \\
55 \% \text { (scope } 1,2,3 \\
\text { vs } 2018 \text { ) }\end{array}$ & $\begin{array}{l}\text { - Addresses the need to decline oil \& gas } \\
\text { production } \\
\text { More in line with carbon budget } \\
\text { approach - need to invest in not only } \\
\text { fewer assets but also assets with lower } \\
\text { emissions. }\end{array}$ \\
\hline
\end{tabular}

Source: Authors. ${ }^{*}$ Equity basis means companies are only responsible for the $\%$ pro rata on their equity. Operated basis means that even if they own $5 \%$ but operate the entire field, then they would be responsible for emissions associated with operations. 


\section{Sector outlook under Paris-aligned scenarios}

The section of the report now changes focus to the use of modelling to explore prospects for future extraction of oil and gas under ambitious climate policies. The focus here is on the types of oil and gas resources extracted in different regions, accounting for declining demand, the carbon intensity of production, and the economics of extracting such resources. The purpose of the modelling is to show what resources, based on economics and carbon intensity, may still be able to be extracted in future years, in a declining market.

The section covers three specific areas; 4.1 ) a review of the publically available information on carbon intensity of production; 4.2 ) the implementation of these assumptions in the model TIAM-UCL, and iii) the key results from a $2^{\circ} \mathrm{C}$-compliant analysis using the updated model. In particular, we focus on varying Scope 1 and 2 (where energy inputs are required into the production and upgrading process) emissions to account for the inherent uncertainty in these values across regions and geological categories.

\subsection{Field-/resource-level carbon intensity database}

Specific efforts were first put into updating carbon intensity values of different resources across regions. These values were collected specifically for upstream production processes (scope 1), ending with the production of a representative barrel of crude oil. In this way, the processes in the global energy systems model TIAM-UCL could be compared more accurately and robustly with a common energy commodity output. A further reason for specifically focusing on upstream and not downstream emissions in the carbon intensity calculation is that the inclusion of the latter can yield lower lifecycle GHG emissions for some high carbon intensity upstream fuels, if the downstream consumption of the fuel is in more efficient vehicles / industrial facilities / power generation plants.

The carbon intensity of fossil fuel production varies significantly across different regions and resource categories. Therefore a literature review established the range of carbon intensity values across the different regions and resource categories of TIAM-UCL. The carbon intensity of oil and gas is driven by multiple factors, including:

- The stringency of environmental regulations and the capability/political desire to enforce the utilisation of natural gas, rather than flaring / burning it into the atmosphere;

- Geology of the reservoir (i.e. geological category) and chemical composition of hydrocarbon compounds (e.g. presence of high concentrations of $\mathrm{H}_{2} \mathrm{~S}$ or $\mathrm{CO}_{2}$ );

- Life-stage of the producing asset, with more depleted fields likely to be higher carbon intensity;

- Geographical location of the field and in particular its proximity to gathering infrastructure and/or demand centres (notably for natural gas or oil fields with associated gas). 
Figure 5 shows the distribution of carbon intensities for a sample of 267 conventional oil fields from different regions, and at different stages of their life-time. In general, heavily depleted fields will have higher carbon intensities given higher energy requirements / lower production rates (e.g. using enhanced oil recovery).

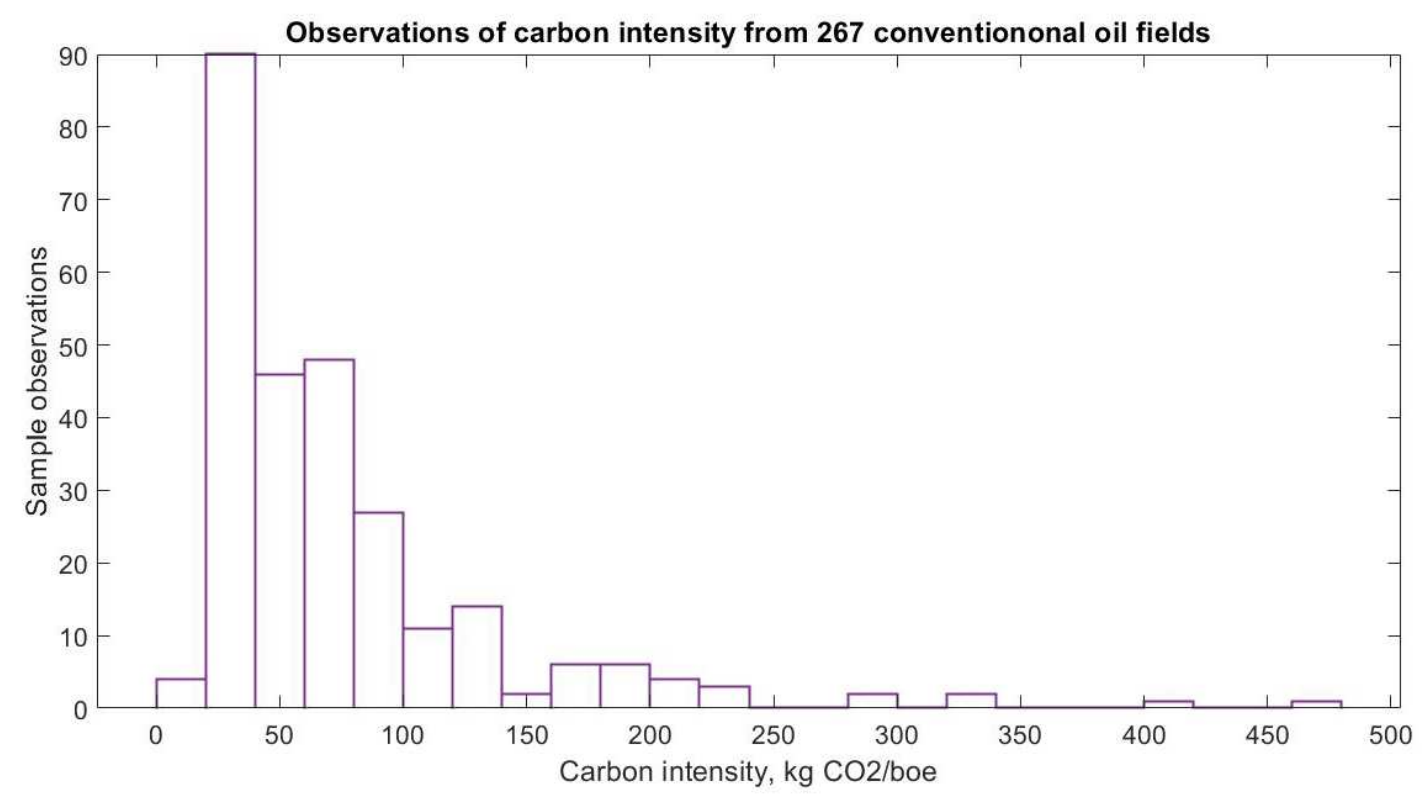

Figure 5. Sample observations of field-level carbon intensities for conventional oil

In addition to conventional oil fields, carbon intensity ranges for oil produced from tight sandstone formations (light tight oil) and heavy oils (oil sands, kerogen and ultra-heavy oil) were also collected. Table 4 shows the sources used in this study; in the case of oil sands in particular, some of the data collected and reported within the academic papers are taken from consultations with industry. 
Table 4. Sources reporting carbon intensity for different categories of oil

\begin{tabular}{|c|c|c|c|}
\hline Source & Year & Oil category & Data disaggregation ${ }^{2}$ \\
\hline ICCT & 2010, 2014 & $\begin{array}{l}\text { Conventional, oil sands, } \\
\text { ultra-heavy, tight oil }\end{array}$ & Field-/play-level \\
\hline OCl & 2019 & $\begin{array}{l}\text { Conventional, oil sands, } \\
\text { ultra-heavy, tight oil }\end{array}$ & Field-/play-level \\
\hline Pacheco et. al & 2019 & Oil sands & $\begin{array}{l}\text { Field-/project-level and company level } \\
\text { upgrading data }\end{array}$ \\
\hline Charpentier et. al & 2010 & Oil sands & Field/-project-level \\
\hline Mui et. al & 2010 & $\begin{array}{l}\text { Oil sands, ultra-heavy, oil } \\
\text { kerogen }\end{array}$ & $\begin{array}{l}\text { Technology specific ranges (e.g. in-situ } \\
\text { vs. mined) }\end{array}$ \\
\hline IHS & 2010 & Oil sands & Aggregate Canadian intensity range \\
\hline Cai et. al & 2015 & Oil sands & $\begin{array}{l}\text { Aggregated at Canadian level but } \\
\text { distinguishes between mined and in-situ }\end{array}$ \\
\hline Wood Mackenzie & 2018 & $\begin{array}{l}\text { Conventional, oil sands, } \\
\text { ultra-heavy, tight oil }\end{array}$ & $\begin{array}{l}\text { Aggregated global figures, with some } \\
\text { examples of field-level ranges }\end{array}$ \\
\hline Ghandi et. al & 2015 & Tight oil & Eagle Ford play \\
\hline Brandt et. al & 2016 & Tight oil & Bakken play \\
\hline Siirde et. al & 2013 & Shale oil (kerogen) & Estonia \\
\hline Laurenzi et. al & 2016 & Tight oil & Bakken \\
\hline
\end{tabular}

Table 5 below shows summary results from the literature review undertaken, and in particular places each category of oil against a threshold $\mathrm{CO}_{2}$ intensity, and the percentage of the sample which was less than or equal to that threshold.

Table 5. Percentage of sample carbon intensities from each resource category which are below certain intensity thresholds

\begin{tabular}{|llll|}
\hline $\begin{array}{l}\text { Sample threshold, } \\
\mathrm{kg} \mathrm{CO}_{2} / \text { boe }\end{array}$ & $\begin{array}{l}\text { Conventional oil } \\
(267), \% \text { sample }< \\
\text { marker }\end{array}$ & $\begin{array}{l}\text { Light shale and tight } \\
\text { oil (25), \% sample }< \\
\text { marker }\end{array}$ & $\begin{array}{l}\text { Heavy and ultra- } \\
\text { heavy oil }^{3}(\mathbf{7 5}), \% \\
\text { sample < marker }\end{array}$ \\
\hline $\mathbf{2 5}$ & 10 & 16 & 1 \\
\hline $\mathbf{5 0}$ & 43 & 32 & 2 \\
\hline $\mathbf{7 5}$ & 70 & 88 & 9 \\
\hline $\mathbf{1 0 0}$ & 80 & 92 & 29 \\
\hline $\mathbf{1 5 0}$ & 90 & 96 & 63 \\
\hline $\mathbf{2 0 0}$ & 96 & 100 & 85 \\
\hline
\end{tabular}

Note. For reference, the number in brackets after each resource group in the column header refers to the size of the sample collected.

As expected, the data shows that heavier unconventional oil has a much higher proportion of the sample (fields) in the higher intensity categories. Finally, Figure 6 shows the output percentile plots from the literature review, and overall range of carbon intensities.

\footnotetext{
${ }^{2}$ This concerns whether the data was reported at a field-/project-/play-level and therefore facilitated exploring some options to weight the individual carbon intensities based on resource endowment etc.

${ }^{3}$ Includes ultra-heavy oil deposits such as those found in Venezuela, Canadian oil sands (both from in-situ and mined production technologies), and crude oil derived from high viscosity kerogen. Therefore shale oil (synthetic crude oil derived from cracking kerogen at high temperatures either at the surface or in-situ) should not be confused with light tight oil, which is found in shale and tight sandstone source rock but is of a much lower viscosity similar to conventional oil.
} 


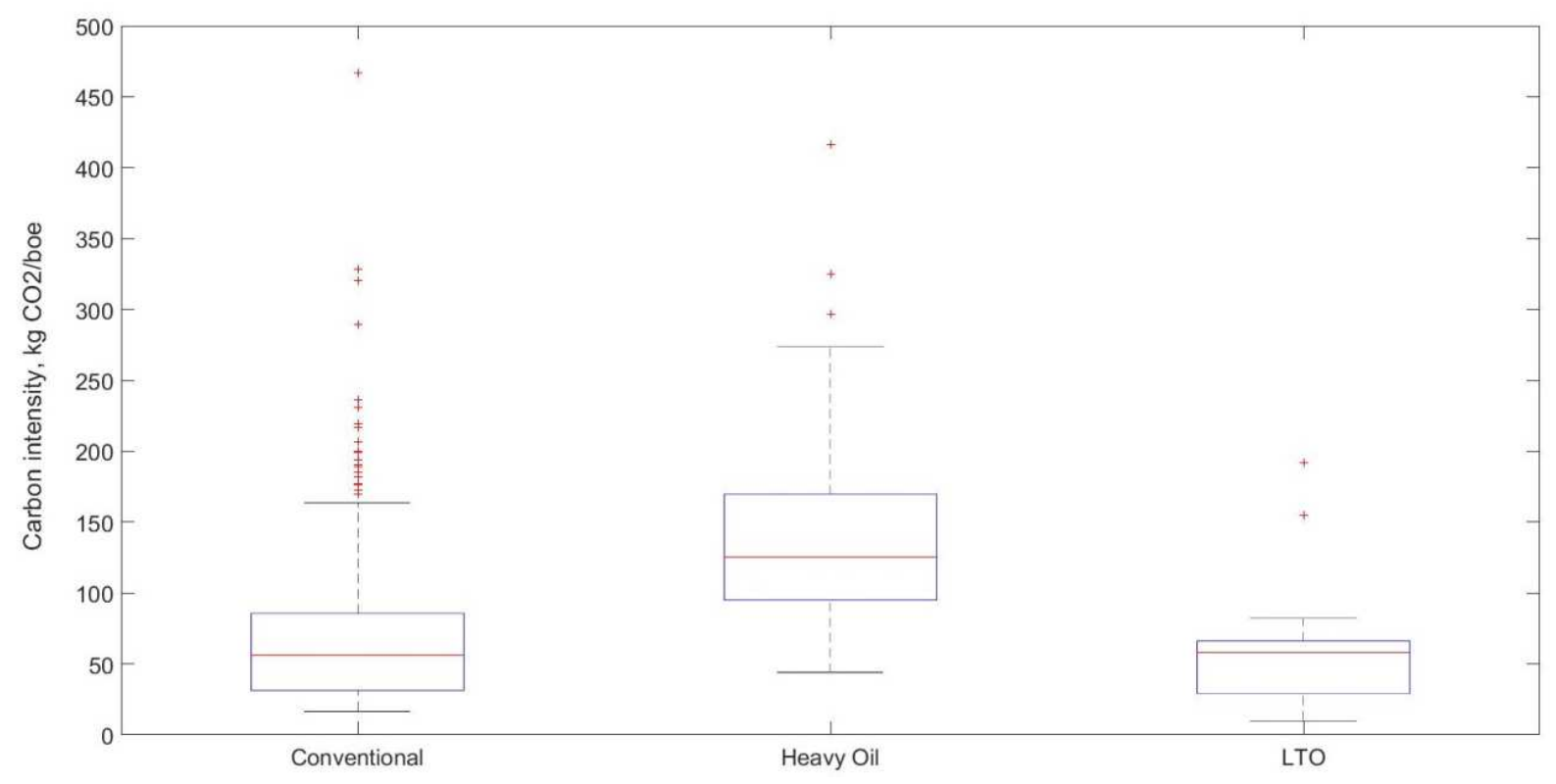

Figure 6. Assessment of literature ranges of carbon intensities for different categories of oil. The red line in each box plot refers to the median (P50) value, whilst the purple bottom and top of each box refer to the $25^{\text {th }}$ and $75^{\text {th }}$ percentiles, respectively. The extension of the whiskers corresponds roughly to the $10^{\text {th }}$ and $90^{\text {th }}$ percentiles.

For light tight oil (LTO in Figure 6), a couple of caveats should be noted. Firstly, only 25 data points could be collected and therefore the sample is relatively small. Secondly, the expansion of light tight oil production in the United States is a relatively recent development in energy markets, and therefore more extended analysis over time of carbon intensities of tight oil wells is required, particularly given the production dynamics of rapid ramp-ups in production, and rapid decline once peak production has been reached. For reference, sensitivities around these values are used either directly or indirectly in the energy systems model TIAM-UCL, with the implementation of region and resource-specific carbon intensities discussed next.

\section{Natural gas resources}

The carbon intensity of natural gas is largely driven by two main factors:

- The concentration of impurities (ppm) which must be stripped from the methane in a processing plant, including $\mathrm{CO}_{2}$ and $\mathrm{H}_{2} \mathrm{~S}$

- The levels of fugitive methane leakage from the system, which is driven by a range of factors including:

- The production methods required, e.g. unconventional extraction requiring hydraulic fracturing;

- Depreciation of production and distribution infrastructure.

The issue of methane leakage has generated increased interest and divergent estimates across the literature in recent years, driven in large part by the expansion of unconventional gas production in the United States. For example, Balcombe et al. (2015) conducted a systematic literature review of estimates of methane leakage across the supply chain and concluded that some processes which are prominent in unconventional gas production (e.g. 
unloading liquids from the gas well) were significant drivers of emissions intensity; the scale of methane leakage is currently a significant debate across academe and industry, as reflected in the literature estimates gathered by Balcombe et al. (2015) ranging from 0.2$10 \%$ of gas supply being leaked into the atmosphere, although aggregated (i.e. conventional and unconventional) median estimates are $\sim 2 \%$. Additionally, a recent study using satellite imagery to estimate methane leakage from the Permian Basin in Texas estimated $3.7 \%$ of the gas extracted was being lost (i.e. as non-combusted methane) into the atmosphere (Zhang et. al, 2020).

\subsection{Implementation of carbon intensity metrics and mitigation measures in TIAM-UCL}

\section{Conventional oil and light tight oil}

Conventional oil normally requires significantly less energy input when compared to some unconventional oils. This is for two main reasons:

- Assuming the field is not highly depleted ${ }^{4}$, the natural pressure within the reservoir is often enough to bring the oil to surface;

- Once extracted, the oil composition is such that less upgrading is required to yield a barrel of crude oil. However, there are significant variations by region in terms of processing requirements to strip the oil of impurities such as sulphur and solution gas. In short, 'sweeter' blends of crude are often developed into gasoline mixes for road vehicle combustion etc., whereas sour and heavier crudes often supply marine bunkers.

Much of the carbon intensity factor for these resources is made up of associated gas that is flared off. From a country-level perspective, this is the key driver in Cameroon having one of the highest carbon intensities of oil production of all countries (Masanadi et. al, 2018; $I C C T, 2014)$. Using region-specific percentile outputs from the range of carbon intensities discussed previously, flaring intensities in each region were altered in TIAM-UCL, with additional adjustments based on gas-to-oil ratios from a range of oil fields (i.e. the concentration of associated natural gas). This is particularly important for undeveloped fields to assess the potential carbon intensity of production, in the case of unmitigated flaring. The first model iteration conducted used the central, i.e. $50^{\text {th }}$ percentile (or median), output for each region from the range of carbon intensities in the database. The $50^{\text {th }}$ percentile carbon intensities for each region were weighted based on the oil reserves of each field, as well as an additional inflator based on a weighted estimate of gas-to-oil ratios in each region.

These new regional inputs yielded a flaring volume in 2020 of $\sim 260 \mathrm{Mt} \mathrm{CO}$, or alternatively around $4 \%$ lower than IEA estimates (IEA, 2019). Additionally, light tight oil is modelled in the same upstream upgrading process (to output a barrel of crude oil) as conventional crude oil. This is due to the fact that the API gravity ${ }^{5}$ of light tight oil is similar to that of conventional crude, and therefore is considered separately from kerogen oil from shale

\footnotetext{
${ }^{4}$ If the field is heavily depleted and flow rates are sub-economical, enhanced oil recovery is often pursued whereby gas and/or liquid (e.g. water injection) is pumped back into the reservoir in order to increase pressure/lower viscosity (e.g. through gas adsorption etc.) and therefore increase flow rates

${ }^{5}$ American Petroleum Institute index of oil gravity. A low API would signify the oil is lower density and therefore has lower viscosity, increasing the flow characteristics of the liquid.
} 
source rock, which requires additional upgrading in a similar way to oil sands and ultraheavy oil, given its high viscosity. Therefore, whilst light tight oil from tight sands and shale rock often requires hydraulic fracturing and therefore higher energy and material inputs, the output oil requires far less upgrading than a kerogen-based alternative. In order to account for these differences, the carbon intensity for tight oil plays in the United States are weighted based on the proportion of recoverable tight oil resources in TIAM-UCL compared to conventional oil, and the carbon intensity of conventional oil adjusted accordingly.

\section{Ultra-heavy oil, oil sands, and kerogen oil}

Unlike conventional oil, the main driver of carbon intensity for ultra-heavy, oil sands, and kerogen oil, is the energy input required to extract and upgrade the high viscosity liquids into a like-for-like barrel of crude oil. For reference, kerogen oil is a high viscosity substance often found in shale source rock, however it requires cracking (i.e. heating the organic compound, usually with chemical catalysts, to extract crude oil). Therefore, sensitivities were conducted on the energy input requirements for synthetic crude oil production from oil sands (bitumen), kerogen, and ultra-heavy oil.

Wang et. al (2016) and Englander and Brandt (2014) provide ranges of energy inputs required firstly to extract bitumen, both from mining and in-situ production techniques, and secondly to produce a barrel of synthetic crude oil through upgrading processes. Therefore, a central estimate of energy input requirements was derived, and the carbon intensity of these processes checked using the emissions coefficients in TIAM-UCL to ensure they were consistent with the literature range. For Canadian oil sands production, this translated into a carbon intensity of $\sim 102 \mathrm{~kg} \mathrm{CO}_{2} /$ boe for the production of a barrel of synthetic crude oil from in-situ production and $\sim 64 \mathrm{~kg} \mathrm{CO} /$ boe from mined oil sands. Table 6 shows the range of energy input requirements to produce a barrel of synthetic crude oil from Canadian oil sands projects.

Table 6. Energy input requirement ranges to produce a barrel of synthetic crude oil (SCO), GJ/GJ

\begin{tabular}{|llll|}
$\begin{array}{l}\text { Primary production } \\
\text { process }\end{array}$ & Natural gas, GJ/GJ (SCO) & Coke, GJ/GJ (SCO) & Electricity, GJ/GJ (SCO) \\
\hline Mined & $0.06-0.14$ & $0.02-0.04$ & $0.03-0.05$ \\
\hline In-situ & $0.22-0.32$ & $0.03-0.06$ & $0.03-0.04$ \\
\hline
\end{tabular}

Given that the secondary upgrading process in TIAM-UCL aggregates the mined outputs of in-situ bitumen and ultra-heavy oil into a single process (the upgrading requirements to generate a barrel of synthetic crude oil), the input parameters for ultra-heavy oil were inflated/deflated in each region based on the same proportion as the literature range for insitu bitumen.

\section{Natural gas}

In order to estimate the impact on the supply of natural gas in a climate change scenario keeping the average global temperature increase below $2^{\circ} \mathrm{C}$, TIAM-UCL was used to run sensitivities around methane leakage rates, and crucially provide insights into how unregulated gas supply chains erode the role of natural gas in future decarbonisation pathways. Table 7 below shows the methane leakage rates from the production, gathering 
and processing of natural gas, assumed for the low, central and high sensitivity runs in TIAM-UCL. ${ }^{6}$ These were generated using the median, $10^{\text {th }}$, and $90^{\text {th }}$ percentiles.

Table 7. Range of methane leakage rates used in TIAM-UCL

\begin{tabular}{|llll|}
\hline Resource category & Leakage rate $\left(\mathbf{1 0 ^ { \text { th } }}\right), \%$ & Leakage rate $($ median $), \%$ & Leakage rate $\left(90^{\text {th }}\right), \%$ \\
\hline Conventional & 0.19 & 1.42 & 2.96 \\
\hline Unconventional & 0.58 & 2.5 & 6.18 \\
\hline
\end{tabular}

Mitigation options to reduce carbon intensity of production in TIAM-UCL

\section{Conventional and tight oil}

TIAM-UCL has a range of options to lower the carbon intensity of production from conventional and tight oil:

- There are options within the model to flare any excess natural gas rather than vent it, i.e. turning emissions of $\mathrm{CH}_{4}$ into combusted $\mathrm{CO}_{2}$. However, given the huge challenge of reducing emissions across the energy system, this option is not widely utilised in the below$2^{\circ} \mathrm{C}$ scenario used in this analysis.

- The second mitigation option involves building more capacity to produce and utilise associated natural gas. TIAM-UCL has been recently updated to include data on the availability of associated gas gathering and processing capacity, as well as the corresponding costs associated with this processing (Welsby, 2018).

- Where conventional oil production requires energy inputs (e.g. electricity), these can be derived from low-carbon sources, although this is a very limited contributor to overall carbon intensity for conventional fuels.

\section{Unconventional: oil sands, ultra-heavy and kerogen oil}

For unconventional fuels, the main mitigation option available to the model to reduce the upstream carbon intensity of production is to switch to low-carbon energy inputs in the production and upgrading processes. For example, oil sands production requires steam to heat the bitumen (whether this is surface mining or in-situ steam-assisted gravity drainage). At present, the majority of the heat input to generate steam is derived from combusting natural gas, with the energy requirements in the upgrading process using petroleum coke, natural gas, diesel and electricity in varying shares (Wang et. al, 2016). Therefore, the use of low-carbon sources could feasibly reduce the carbon intensity of heavy oil production. However, pathways for these remain particularly uncertain, with biomass as a source of heat for steam generation highly unlikely given biomass will be in huge demand in other sectors e.g. power generation and transport fuels, using biomass with carbon capture and storage (BECCS). Additionally, the potential to use hydrogen seems doubtful given demand from other sectors.

\section{Natural gas}

The main mitigation options available to limit the leakage of natural gas from the supply chain include proxy technologies for deploying monitoring equipment and oxidising

\footnotetext{
${ }^{6}$ Leakage rates from international pipeline trade are modelled separately.
} 
methane using catalytic converters. For natural gas further downstream, there is the option of deploying CCS either directly for natural gas combustion or in the process of converting natural gas into hydrogen. However given the focus of this research is on upstream emissions intensity, this is not explored in great detail, but is important to note as a caveat to the results discussed in the next section.

\subsection{Scenario analysis of oil and gas production under climate targets}

TIAM-UCL has been run with a climate policy objective of keeping the global average temperature increase to below $2^{\circ} \mathrm{C}$, with sensitivities conducted on the carbon intensity of oil and gas using the data collection described in the previous sections. The main climate policy scenario uses a carbon budget of $960 \mathrm{Gt} \mathrm{CO}_{2}$ between 2018 and 2100, equivalent to keeping warming well below $2^{\circ} \mathrm{C}$ (at a probability exceeding 67\%) (IPCC, 2018). Sensitivity analysis was then conducted based on the previously documented review of different carbon intensities between regions and resource categories.

The output results from the central scenario are presented below, along with a sensitivity analysis which varied the carbon intensity of different oil and gas categories in order to represent the large range of uncertainty inherent with estimating such metrics. For oil, the sensitivity analysis used 'low' $\left(25^{\text {th }}\right)$ and 'high' $\left(75^{\text {th }}\right)$ percentiles from the carbon intensity ranges reported in Section 4.2 in order to assess potential redistribution of production from the central scenario, which uses the median $\left(50^{\text {th }}\right.$ percentile) carbon intensity value. For natural gas, uncertainty in the methane leakage rate was analysed by assessing changes in production using the $25^{\text {th }}$ (P25) and $75^{\text {th }}$ (P75) methane leakage percentiles, from the central scenario which assumed the median ( $50^{\text {th }}$ percentile) methane leakage rate. Box 1 below describes the process in more detail.

\section{Box 1: Method employed to account for uncertainty in estimates of carbon intensity for different categories of oil and gas across different regions}

In the central scenario in this report, we use a carbon budget of $960 \mathrm{Gt} \mathrm{CO}_{2}$ between 2018 and 2100 , equivalent to keeping warming well below $2^{\circ} \mathrm{C}$ (at a probability exceeding $67 \%$ ) (IPCC, 2018). For the carbon intensity values, our central scenario utilises the median $\left(50^{\text {th }}\right.$ percentile or P50) intensity for each region derived from the analysis discussed in Section 4.1. These were input into TIAM-UCL to provide the unmitigated emissions intensity of producing a representative barrel of oil. The model can then decide to employ various mitigation options if it is cost optimal to do so, as discussed in Section 4.2. Therefore, regional variations based on current oil production carbon intensities are taken into account, with an endogenous decision available to mitigate (i.e. reduce) these values if cost optimal.

In order to explore the large range of uncertainty surrounding both present and particularly future carbon intensity levels of crude oil production and methane leakage from natural gas systems, two sensitivities were conducted based on a 'high' and 'low' assumption of regional intensity. For oil, the 'low' sensitivity assumes that regional production intensity is kept to the $25^{\text {th }}$ percentile (P25) of the ranges derived from the literature review. Alternatively, the 'high' intensity assumes regional carbon intensities are at the $75^{\text {th }}$ (P75) percentile level, taken from the ranges described in Section 4.2. As discussed for the central scenario, the model can choose endogenously to apply some mitigation options if this is cost optimal. The 'high' and 'low' sensitivities were applied to all 
regions at the same time for consistency in the analysis and to avoid potentially arbitrary allocation of certain regions as 'better' performers (e.g. exogenously assuming more stringent regulation in one region over another), given significant heterogeneity both within regions and resource categories.

The results of the oil analysis show that when aggregated globally, production changes very little. However there is redistribution between regions in terms of cumulative production. This reflects the heavily binding nature of the carbon budget which gives the model very little room for manoeuvre, and in the case of higher carbon intensities, requires more mitigation options to be deployed by the model, as well as emissions cuts elsewhere (i.e. in other sectors). Figure 9 in the analysis below shows the regional redistribution of cumulative oil production between the central and low and high sensitivities.

For natural gas, the sensitivity analysis focused on uncertainty in methane leakage rates, with the 'low' ( $10^{\text {th }}$ percentile) and 'high' ( $90^{\text {th }}$ percentile) leakage rates compared to the central $\left(50^{\text {th }}\right.$ percentile) scenario (see Table 7 for the range of methane leakage derived in this analysis). Global production in the high methane leakage scenario is approximately 6\% lower in 2030 when compared to the central scenario (or $\sim 260 \mathrm{bcm}$ ). Figure 13 in the analysis below shows the regional redistribution of cumulative gas production between the central and low and high sensitivities. 
Before analysing the results of the climate policy scenario in TIAM-UCL, Figure 7 shows the supply cost curve for oil split between region (a) and resource category (b).

a)

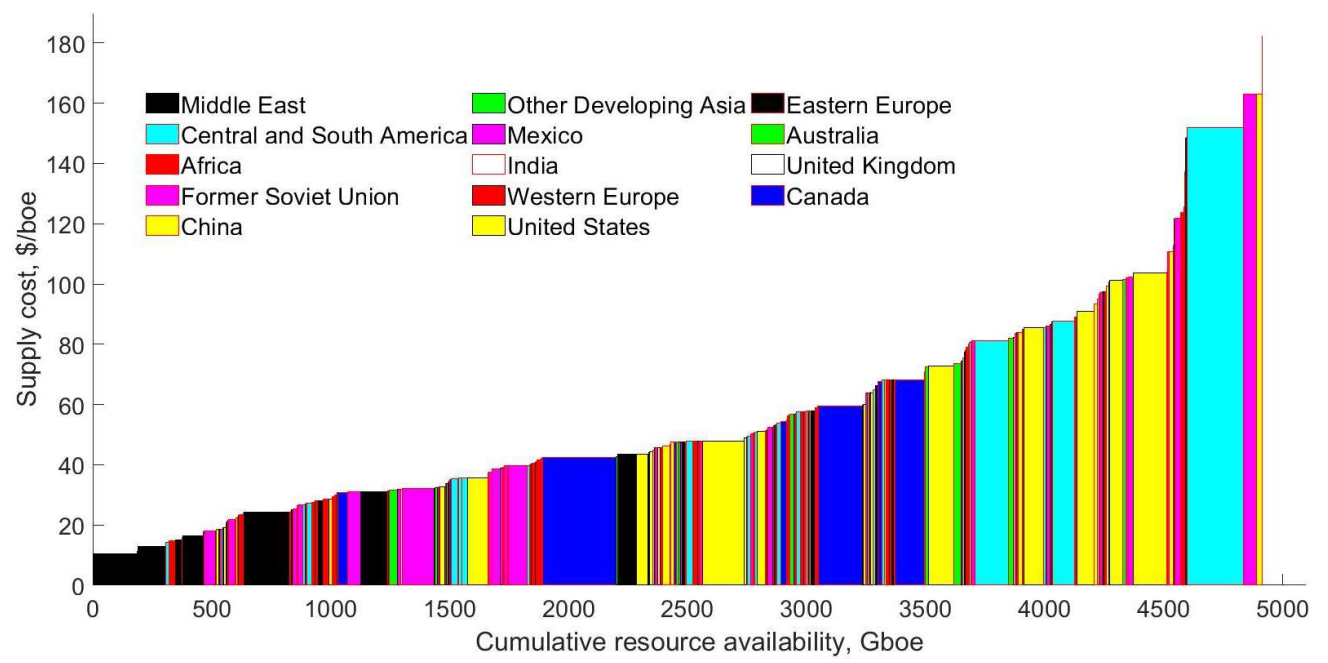

b)

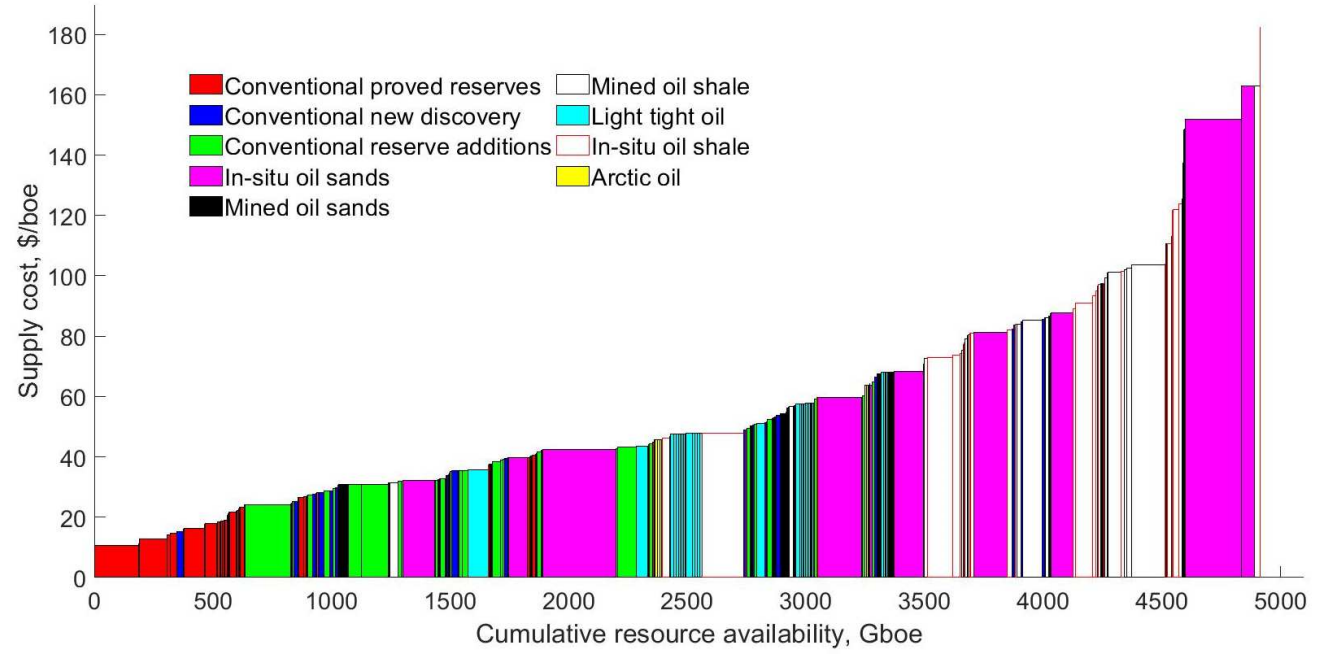

Figure 7. Oil supply cost curve from 2015 by a) TIAM-UCL region and b) resource category (Source: McGlade, 2013; authors own updates)

When aggregated globally, oil supply in the scenario remains inelastic to variations in carbon intensity for two main reasons:

1. The stringency of the climate constraint leaves very little room for manoeuvre in the model, with higher-carbon upstream production for unconventional heavy oils phased out of the energy system regardless of the energy input sensitivities. In particular, the previously mentioned mitigation options available to the model (e.g. using biomass or hydrogen as a lower-carbon feedstock to produce steam) are not picked up due to the cost of such processes, and the competition for biomass and hydrogen from other sectors. By 2030, heavy oils (ultra-heavy, oil sands, and shale oil) supply $2 \%$ of global oil in the low and central carbon intensity cases, and $1 \%$ in the high carbon intensity case. 
2. Oil demand destruction means supply can be dominated by the traditional, lower-cost, large exporters (e.g. Middle Eastern OPEC countries). The distributional and socio-political consequences of this are of huge importance, but outside the remit of this report.

Figure 8 shows global oil supply by region (a) and resource category (b) in the central scenario (i.e. median regional and resource category carbon intensity inputs). As noted above, conventional and light tight oil dominate production going forward, with no room for the more polluting (and higher cost) unconventional resources. As mentioned above, due to the objective function of TIAM-UCL being the minimisation of energy system costs given a large range of constraints, an exploration of the distributional impacts of this concentration of production, and more granular details of oil market dynamics (e.g. fiscal regimes) would be required. However, two main conclusions can be drawn:

1. High carbon intensity upstream production of heavy oil in combination with higher costs for energy inputs sees these types of oil phased out of the energy system;

2. From both a cost and climate policy perspective, using lower-carbon energy inputs (biomass and hydrogen derived from electrolysis or steam methane reforming with CCS (SMR-CCS)) to extract and upgrade heavy oil is non-optimal, particularly given that the consumption of these fuels would forgo consumption in other sectors (e.g. power and transport fuel using BECCS). 
a)
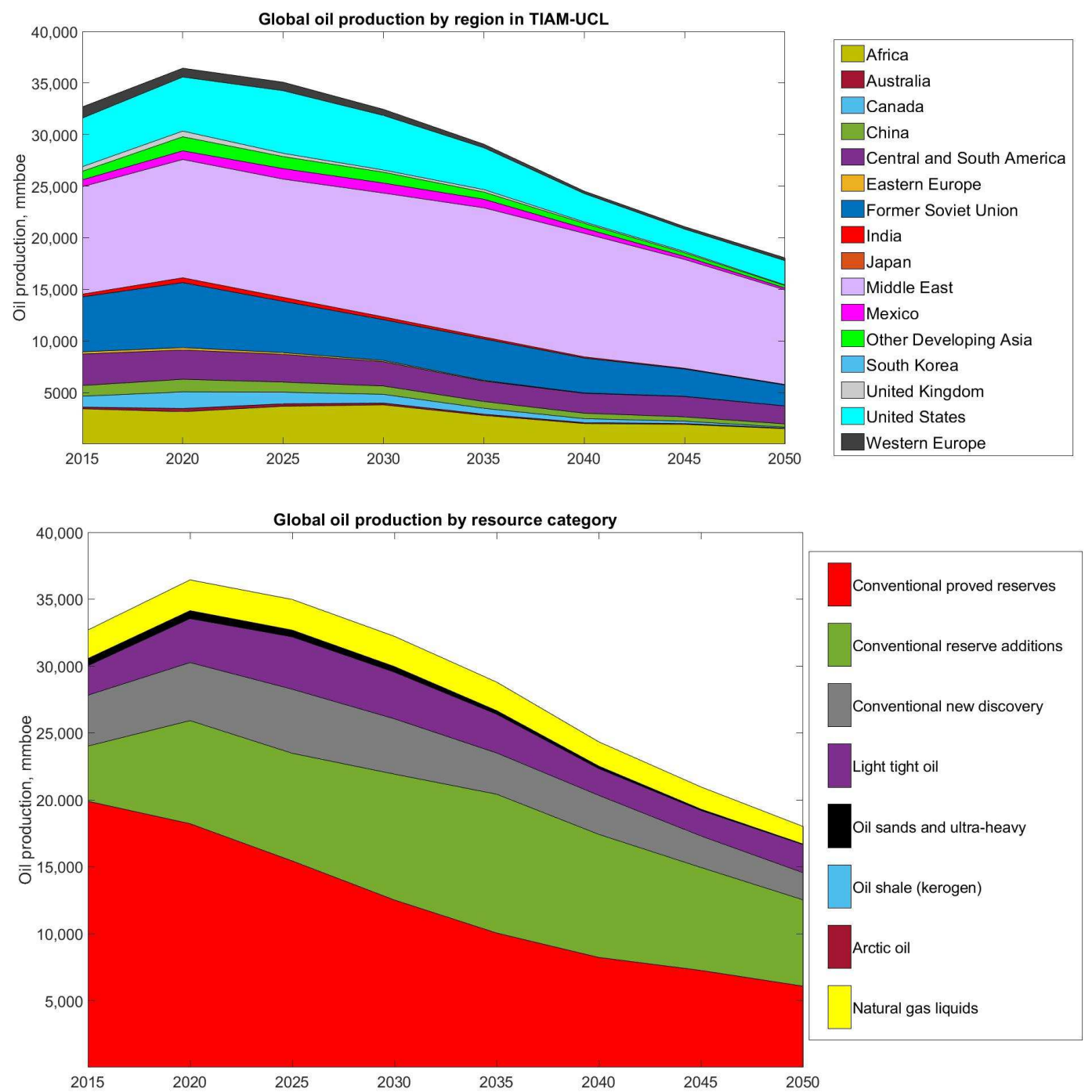

b)

Figure 8. Global oil production by a) region and b) resource category (Source: TIAM-UCL modelling)

Figure 9 shows the cumulative (2020-2050) change in regional production relative to the central case for the low and high sensitivities, respectively. We calculated this by subtracting cumulative regional production (2020-2050) in the central carbon intensity case from the low and high sensitivities. Therefore, any negative production change signifies that production is lower in the sensitivity analysis compared to the central scenario, and vice versa for positive production change. 
a)

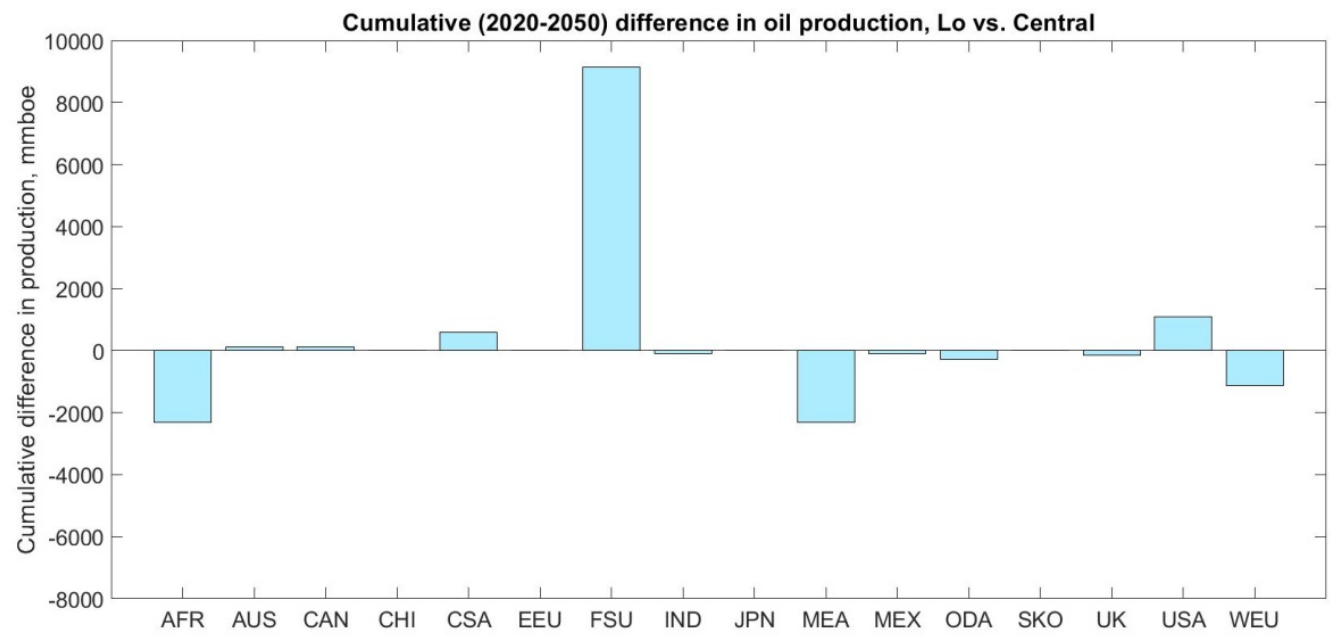

b)

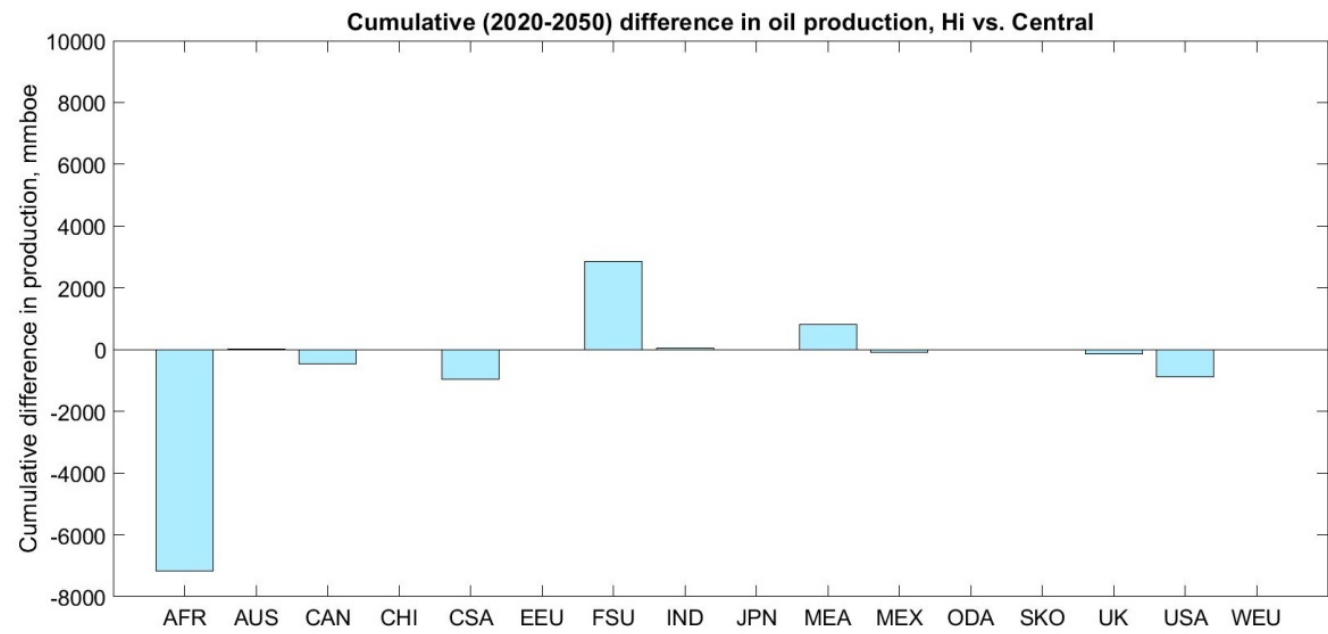

Figure 9. Cumulative production change between the central carbon intensity value for oil and the a) ('Lo' $25^{\text {th }}$ percentile carbon intensity) and b) high ('Hi' $-75^{\text {th }}$ percentile carbon intensity) cases (Source: TIAM-UCL modelling)

The change in production can be explained by a combination of the carbon intensities of production and the cost of extraction for the remaining resource base. Figure 10 shows a range of carbon intensities for conventional oil, and shows why African production is highly sensitive when competing against other regions for both the lower and higher carbon intensities (i.e. the carbon intensity of crude oil production for Africa in both the low and high sensitivity cases is higher relative to other regions). Additionally, it may seem counterintuitive that the Former Soviet Union (FSU) sees cumulative production increase above the central carbon intensity sensitivity for both the high and low cases. However, this can be explained by a range of factors and caveats which should be noted here:

- The Middle East produces up to an exogenous constraint placed on OPEC production for all sensitivities out to 2035 (i.e. to stop the model producing unrealistic amounts of the cheapest source of oil); 
- The Former Soviet Union has a large resource base and overall supply costs for categories of conventional oil are generally more cost-effective in the model (see

- Figure 7a);

- In all three sensitivities, oil production in Former Soviet Union is declining. The sensitivity analysis merely suggests that the rate of production decline as the global energy system rapidly decarbonises changes depending on the relative carbon intensity of oil production in the Former Soviet Union and in other regions.

- Some developed regions in the model (USA, Western Europe and Canada) drive decarbonisation across the energy system given lower technology costs for the large deployment of renewables etc., and therefore allow more of the carbon budget to be used up by existing large fossil exporters.

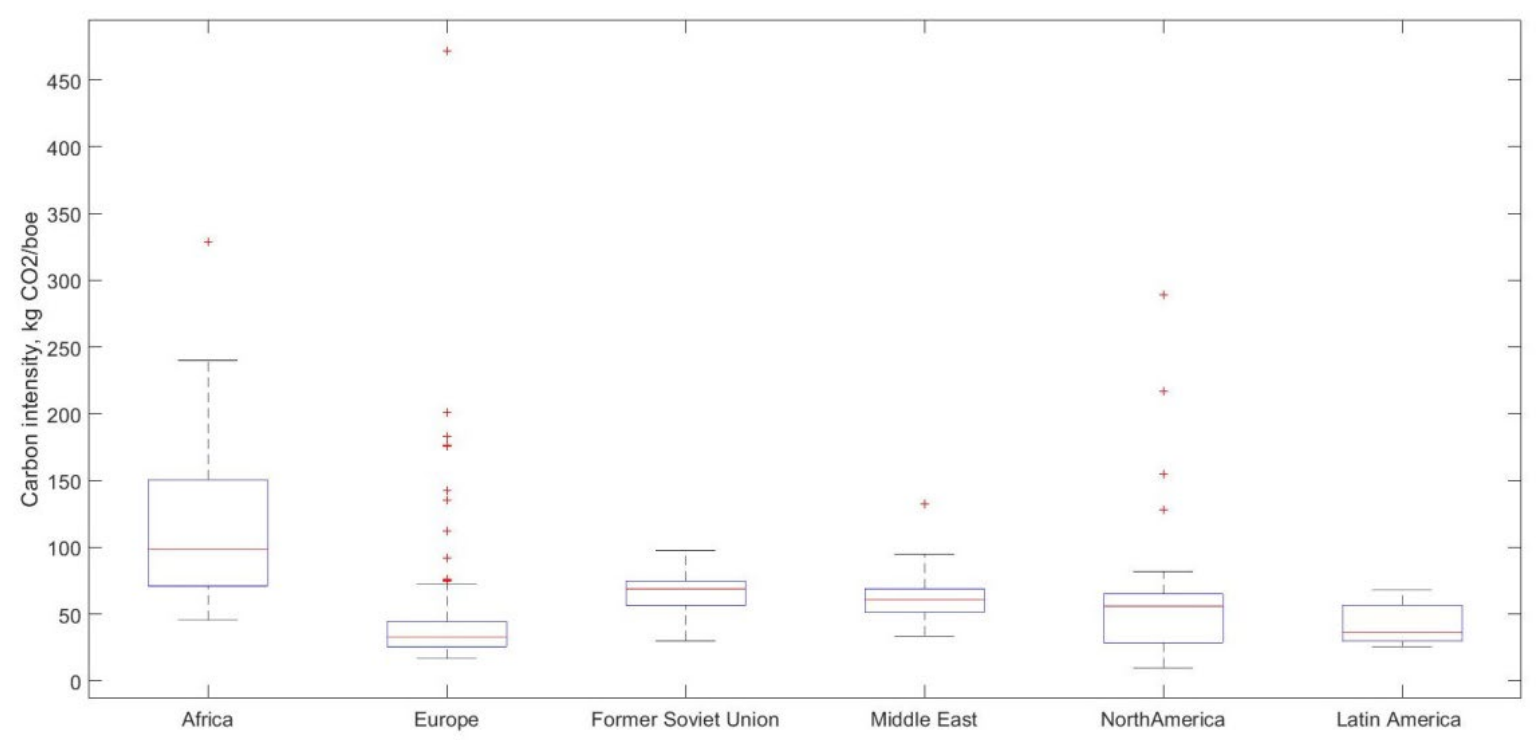

Figure 10. Carbon intensity for conventional oil across different regions. As with Figure 6, the red line in each box plot refers to the median (P50) value, whilst the purple bottom and top of each box refer to the $25^{\text {th }}$ and $75^{\text {th }}$ percentiles, respectively.

\subsection{Implications for oil producers across different regions}

The cumulative oil production shown in Figure $8 \mathrm{~b}$ for the 2020-2050 period (and further disaggregated in Table 8) suggests that some regions will be at higher risk of having stranded oil assets based on the size, oil type and geology of their reserves, as well as their extraction costs. 
Table 8. Cumulative oil production (2020-2050) in TIAM-UCL in a well below $2^{\circ} \mathrm{C}$ scenario (Gboe)

\begin{tabular}{|c|c|c|c|c|c|c|c|c|}
\hline & $\begin{array}{c}\text { Conventional } \\
\text { Proved } \\
\text { Reserves }\end{array}$ & $\begin{array}{c}\text { Conventional } \\
\text { Reserve } \\
\text { Additions }\end{array}$ & $\begin{array}{c}\text { Conventional } \\
\text { New } \\
\text { Discovery }\end{array}$ & $\begin{array}{l}\text { Light } \\
\text { Tight } \\
\text { Oil }\end{array}$ & $\begin{array}{c}\text { Oil sands } \\
\text { and extra- } \\
\text { heavy }\end{array}$ & $\begin{array}{c}\text { Oil } \\
\text { shale }\end{array}$ & Arctic & NGL \\
\hline AFR & 33 & 30 & 19 & 0 & 0 & 0 & 0 & 5 \\
\hline AUS & 0 & 2 & 0 & 0 & 0 & 0 & 0 & 2 \\
\hline CAN & 1 & 8 & 2 & 0 & 7 & 0 & 0 & 2 \\
\hline CHI & 12 & 8 & 2 & 0 & 0 & 0 & 0 & 0 \\
\hline CSA & 16 & 29 & 17 & 0 & 2 & 0 & 0 & 4 \\
\hline EEU & 1 & 1 & 0 & 0 & 0 & 0 & 0 & 0 \\
\hline FSU & 53 & 39 & 13 & 0 & 1 & 0 & 0 & 6 \\
\hline IND & 1 & 4 & 0 & 0 & 0 & 0 & 0 & 2 \\
\hline JPN & 0 & 0 & 0 & 0 & 0 & 0 & 0 & 0 \\
\hline MEA & 207 & 105 & 27 & 0 & 0 & 0 & 0 & 18 \\
\hline MEX & 2 & 14 & 3 & 0 & 0 & 0 & 0 & 3 \\
\hline ODA & 5 & 9 & 5 & 0 & 0 & 0 & 0 & 5 \\
\hline SKO & 0 & 0 & 0 & 0 & 0 & 0 & 0 & 0 \\
\hline UK & 1 & 5 & 1 & 0 & 0 & 0 & 0 & 1 \\
\hline USA & 8 & 10 & 10 & 84 & 0 & 0 & 0 & 11 \\
\hline WEU & 1 & 4 & 6 & 3 & 0 & 0 & 0 & 2 \\
\hline Global & 342 & 268 & 109 & 77 & 10 & 0 & 0 & 61 \\
\hline
\end{tabular}

A comparison between the cumulative oil production numbers in Table 8 and the estimated reserves and resources in each region (

Table 9) provides some insights into the risk posed for the extraction activities of different oil types. Based on our modelling results, unconventional reserves appear more likely to remain unused. Hence, most of the oil sands and extra-heavy oil from Africa, Canada and the Central and South America regions would probably remain unused in a below $2^{\circ} \mathrm{C}$ scenario. A significant amount of conventional reserves would also need to remain underground; beyond economic considerations, agreeing which countries are to develop their resources and which ones will see their resources stranded remains a contested issue. However, in a below $2^{\circ} \mathrm{C}$ scenario it is clear that those regions with oil reserves that represent a large share of the total global oil budget are likely to see some of their resources stranded (e.g. Canada, Central and South America, Former Soviet Union and the Middle East). 
Table 9. Oil reserves and resources by region and category (Gboe), and percentage used based on Table 8 figures.

\begin{tabular}{|c|c|c|c|c|c|c|c|c|c|c|c|c|c|c|c|c|}
\hline \multirow[t]{2}{*}{ Region } & \multicolumn{2}{|c|}{$\begin{array}{l}\text { Conventional } \\
\text { Proved Reserves }\end{array}$} & \multicolumn{2}{|c|}{$\begin{array}{c}\text { Conventional } \\
\text { Reserve Additions }\end{array}$} & \multicolumn{2}{|c|}{$\begin{array}{c}\text { Conventional New } \\
\text { Discovery }\end{array}$} & \multicolumn{2}{|c|}{ Light Tight Oil } & \multicolumn{2}{|c|}{$\begin{array}{l}\text { Oil sands and } \\
\text { extra-heavy }\end{array}$} & \multicolumn{2}{|c|}{ Oil shale } & \multicolumn{2}{|c|}{ Arctic } & \multicolumn{2}{|c|}{ NGL } \\
\hline & Value & $\%$ used & Value & $\%$ used & Value & $\%$ used & Value & $\%$ used & Value & $\%$ used & Value & $\%$ used & Value & $\%$ used & Value & $\%$ used \\
\hline AFR & 84 & $39 \%$ & 72 & $42 \%$ & 54 & $35 \%$ & 45 & $0 \%$ & 17 & $0 \%$ & 48 & $0 \%$ & 0 & & 21 & $24 \%$ \\
\hline AUS & 2 & $0 \%$ & 5 & $40 \%$ & 1 & $0 \%$ & 18 & $0 \%$ & 0 & & 126 & $0 \%$ & 0 & & 5 & $40 \%$ \\
\hline CAN & 5 & $20 \%$ & 17 & $47 \%$ & 5 & $40 \%$ & 20 & $0 \%$ & 697 & $1 \%$ & 5 & $0 \%$ & 9 & $0 \%$ & 2 & $100 \%$ \\
\hline $\mathrm{CHI}$ & 27 & $44 \%$ & 14 & $57 \%$ & 5 & $40 \%$ & 28 & $0 \%$ & 4 & $0 \%$ & 107 & $0 \%$ & 0 & & 2 & $0 \%$ \\
\hline CSA & 60 & $27 \%$ & 93 & $31 \%$ & 63 & $27 \%$ & 55 & $0 \%$ & 468 & $0 \%$ & 25 & $0 \%$ & 0 & & 14 & $29 \%$ \\
\hline EEU & 3 & $33 \%$ & 4 & $25 \%$ & 1 & $0 \%$ & 4 & $0 \%$ & 0 & & 0 & & 0 & & 0.2 & $0 \%$ \\
\hline FSU & 126 & $42 \%$ & 109 & $36 \%$ & 38 & $34 \%$ & 17 & $0 \%$ & 300 & $0 \%$ & 91 & $0 \%$ & 22 & $0 \%$ & 41 & $15 \%$ \\
\hline IND & 4 & $25 \%$ & 9 & $44 \%$ & 1 & $0 \%$ & 3 & $0 \%$ & 0 & & 0 & & 0 & & 2 & $100 \%$ \\
\hline JPN & 0 & & 0 & & 0 & & 0 & & 0 & & 0 & & 0 & & 0 & \\
\hline MEA & 445 & $47 \%$ & 399 & $26 \%$ & 66 & $41 \%$ & 24 & $0 \%$ & 0 & & 12 & $0 \%$ & 0 & & 85 & $21 \%$ \\
\hline MEX & 13 & $15 \%$ & 30 & $47 \%$ & 8 & $38 \%$ & 14 & $0 \%$ & 0 & & 0 & & 0 & & 3 & $100 \%$ \\
\hline ODA & 13 & $38 \%$ & 20 & $45 \%$ & 12 & $42 \%$ & 16 & $0 \%$ & 2 & $0 \%$ & 3 & $0 \%$ & 0 & & 9 & $56 \%$ \\
\hline SKO & 0 & & 0 & & 0 & & 0 & & 0 & & 0 & & 0 & & 0 & \\
\hline UK & 5 & $20 \%$ & 8 & $63 \%$ & 3 & $33 \%$ & 1 & $0 \%$ & 4 & $0 \%$ & 1 & $0 \%$ & 0 & & 2 & $50 \%$ \\
\hline USA & 24 & $33 \%$ & 52 & $19 \%$ & 34 & $29 \%$ & 167 & $50 \%$ & 21 & $0 \%$ & 627 & $0 \%$ & 20 & $0 \%$ & 22 & $50 \%$ \\
\hline WEU & 9 & $11 \%$ & 12 & $33 \%$ & 10 & $60 \%$ & 20 & $15 \%$ & 2 & $0 \%$ & 27 & $0 \%$ & 14 & $0 \%$ & 11 & $18 \%$ \\
\hline Global & 819 & $42 \%$ & 842 & $32 \%$ & 301 & $36 \%$ & 433 & $18 \%$ & 1515 & $1 \%$ & 1073 & $0 \%$ & 65 & $0 \%$ & 219 & $28 \%$ \\
\hline
\end{tabular}

Source: McGlade (2013), McGlade and Ekins (2015); IEA (2019) 
Naturally, the transition risk exposure by country is different within each region. For example, within Central and South America, Venezuela is likely to see a significant amount of stranded reserves given the oil type of some of them (extra-heavy oil) and the vast size of their overall reserves ( $>150,000$ million barrels); on the other hand, Brazil is better positioned to see stronger development prospects under a wide range of global oil demand scenarios (Solano-Rodriguez et al, 2019). The stranded assets risk has large fiscal implications for countries that depend heavily on oil revenues for their public sector budgets, as well as for international oil companies that are valued based on assumptions that their full reserve base can be produced. Table 10 shows those oil companies holding the largest assets at risk in each region, based on their current holdings. It is clear many of the oil types are those with typically high carbon intensity factors; however, other factors around the economics of production are also critical, for example in the case of Arctic oil.

Table 10. Assets by region and largest shareholders where investment risk may be higher based on current holdings

\begin{tabular}{|c|c|c|c|}
\hline & Ownership & Oil type & Key assets (Bbbl) \\
\hline AFR & $\begin{array}{l}\text { (a)ENI/SNPC, (b)Total/Madagascar Oil, } \\
\text { (c)Tullow Oil/CNOOC/Total }\end{array}$ & $(a, b, c)$ Extra heavy oil & $\begin{array}{l}\text { (a)Tchikatanga (1.5), (b)Bemolanga } \\
\text { (10), (c)Waraga }(0.032)\end{array}$ \\
\hline CAN & $\begin{array}{l}\text { (a)Chevron and Stat Oil, (b)Canadian Oil } \\
\text { Sands Ltd/Imperial/Suncor, } \\
\text { (c)Imperial/ExxonMobil }\end{array}$ & $\begin{array}{l}\text { (a)Arctic, (b,c)Oil } \\
\text { Sands }\end{array}$ & $\begin{array}{l}\text { (a)Canada Arctic (3), (b)Mildred Lake } \\
\text { (5.7), (c)Kearl L.(5.5) }\end{array}$ \\
\hline CSA & (a)PDVSA/Gazprom, (b)PDVSA/Belorusneft & (a)Extra heavy oil & (a)Lagunillas (3.4), (b)Lama(1.2) \\
\hline FSU & (a)Rosneft and ExxonMobil & (a)Arctic & (a)Russia Arctic (29) \\
\hline USA & $\begin{array}{l}\text { (a)Shell, (b)Devon/Chevron/EOG, } \\
\text { (c)Conoco/Phillips (d)BHP/Chesapeake }\end{array}$ & $\begin{array}{l}\text { (a)Arctic, (b,c,d)Tight } \\
\text { Oil }\end{array}$ & $\begin{array}{l}\text { (a)US Arctic (2.1), (b)Permian Basin } \\
\text { Unconventional (40), (c)Bakken } \\
\text { (15.8),(d) Eagle Ford Oil Window } \\
(8.2)\end{array}$ \\
\hline WEU & $\begin{array}{l}\text { (a)Government of Greenland, (b)Statoil } \\
\text { and Rosneft }\end{array}$ & $(a, b)$ Arctic & $\begin{array}{l}\text { (a)Greenland Arctic (4.4), (b)Norway } \\
\text { Arctic (1.5) }\end{array}$ \\
\hline
\end{tabular}

Our modelling results show uncertain production in particular for Africa and the Former Soviet Union countries. Key national oil companies in these regions that could see the largest impact (faster decline for Africa, slower decline for the Former Soviet Union) on their oil revenues are Algeria (Sonatrach), Angola (Sonangol), Libya (Libyan National Oil Corporation), Nigeria (Nigerian National Petroleum Corporation), Russia (Rosneft), Kazakhstan (KazMunayGas) and Azerbaijan (Socar). Although in this study we used OPEC production constraints, it is worth noting that not having them would see an increase in production from the Middle East region until $2030^{7}$ (resulting in reductions elsewhere); especially from the largest regional producers: Saudi Arabia (Saudi Aramco), Iraq (Iraq National Oil Company) and the United Arab Emirates (Abu Dhabi National Oil Company). The risk for these national oil companies is subject to the performance of their oilfields in a below $2^{\circ} \mathrm{C}$ scenario. Insights into the transition risk at field level would require modelling a wide range of scenarios using an oilfield asset model, which is out of the scope of this study.

\footnotetext{
${ }^{7}$ The constraint for Middle Eastern OPEC production is binding until 2030 in a $2^{\circ} \mathrm{C}$ compliant run.
} 


\subsection{Implications for gas producers across different regions}

Before considering uncertainties surrounding carbon intensity ranges for different categories of natural gas, Figure 11 shows the initial distribution of resources in TIAM-UCL from 2015, by region (a) and resource category (b).

a)

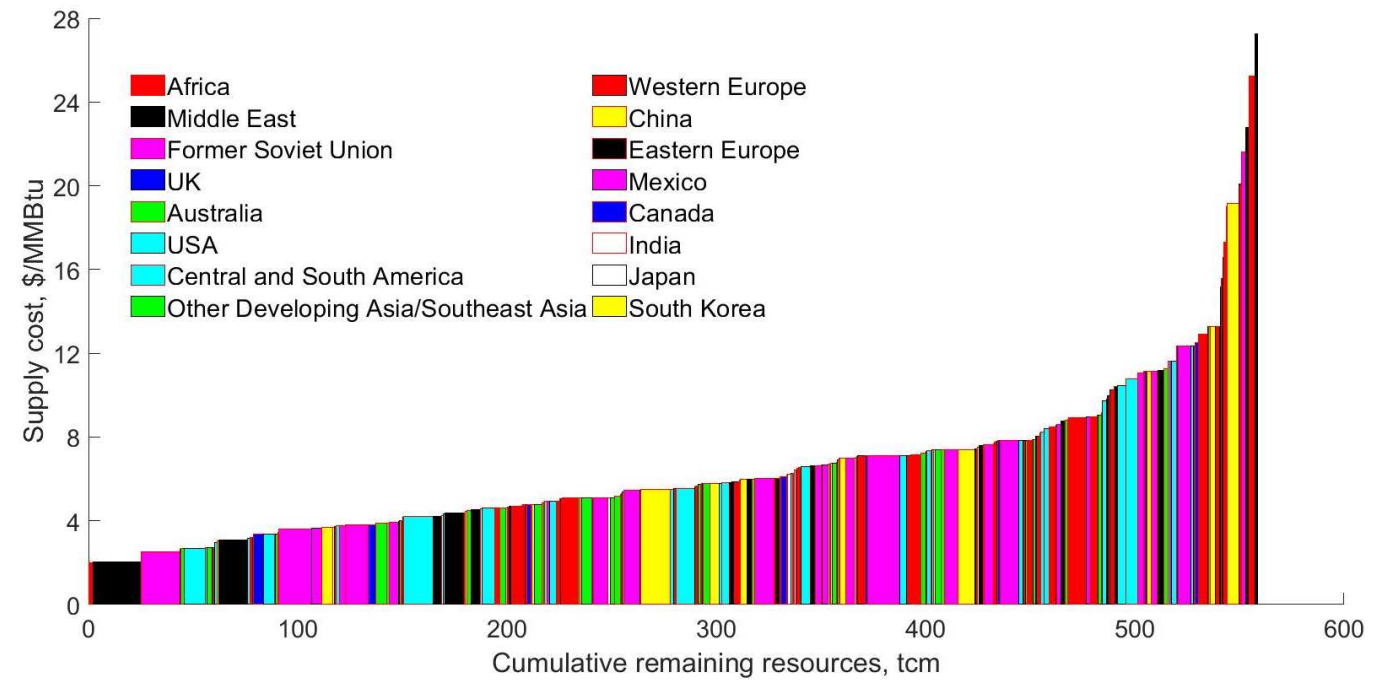

b)

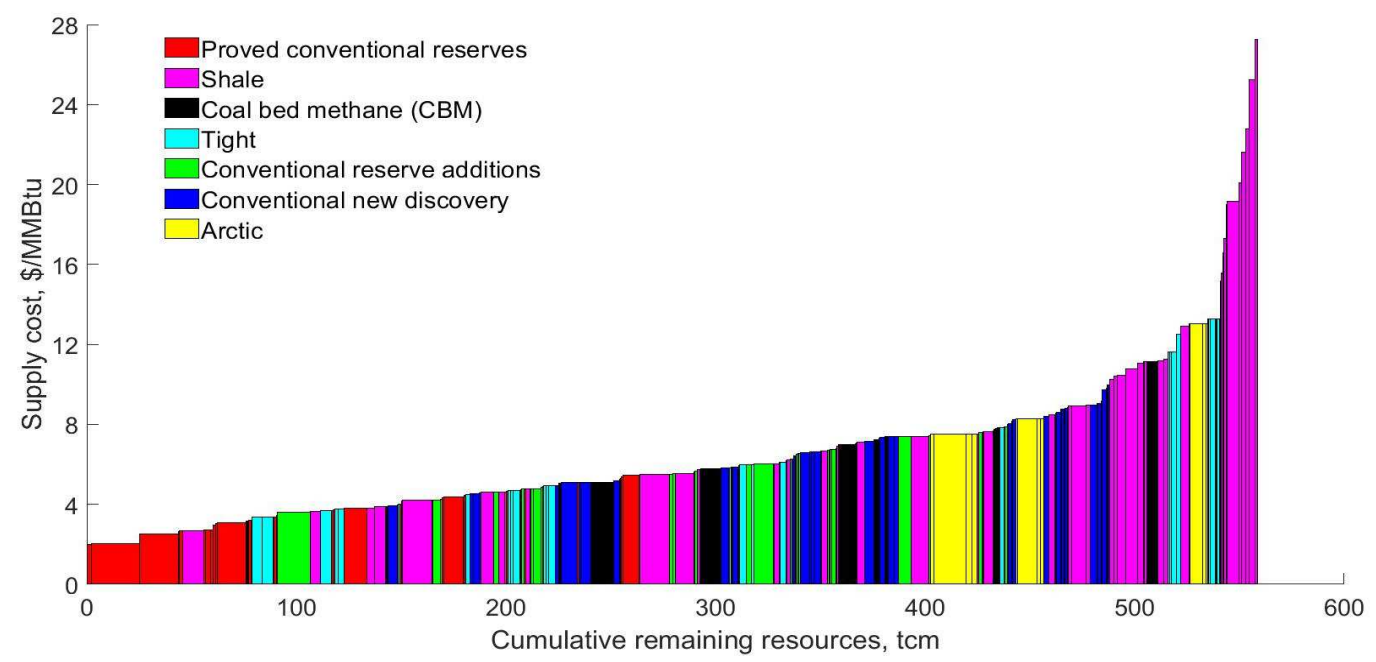

Figure 11. Natural gas supply cost curve from 2015 by a) TIAM-UCL region and b) resource category. Source: Welsby (forthcoming), Welsby (2018), McGlade (2013)

Figure 12 shows natural gas production by region (a) and resource category (b) in the central carbon intensity sensitivity (see Table 7). As described in Box 1 , this uses the median $\left(50^{\text {th }}\right.$ percentile) methane leakage rate. Additionally, Figure 13 (a) and (b) show the cumulative (2020-2050) change in regional production relative to the central case for the low and high sensitivities, respectively. 
a)

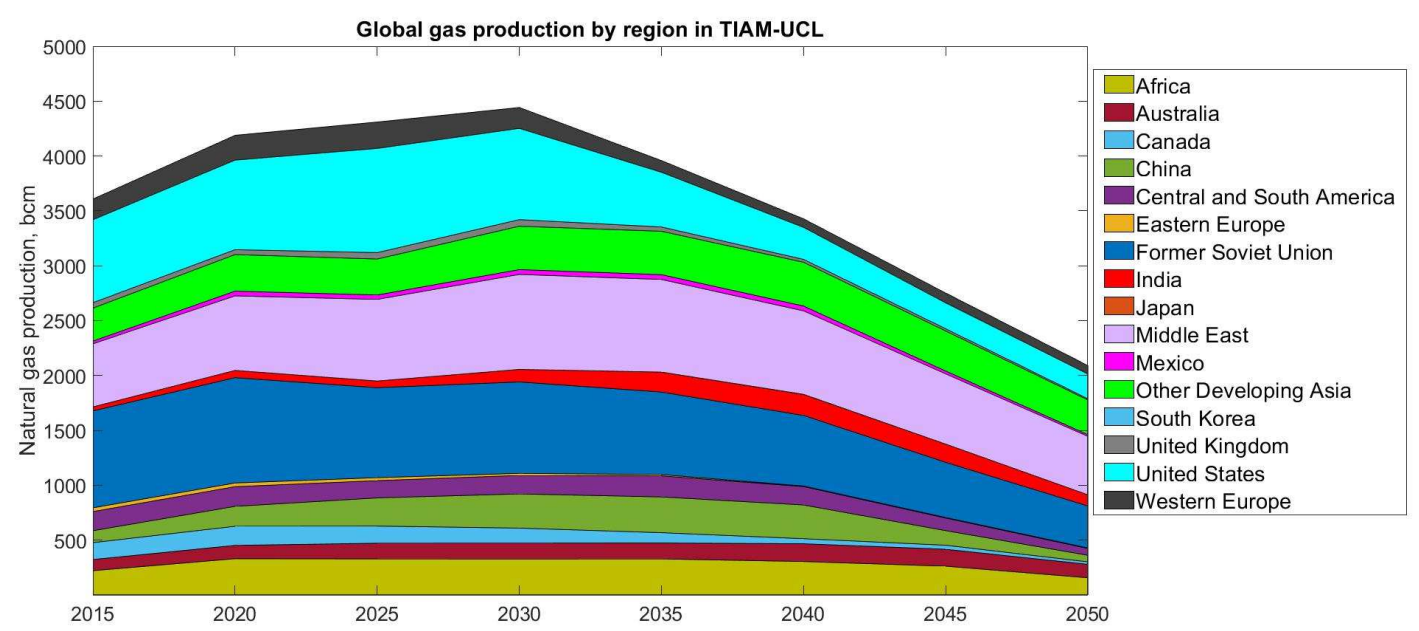

b)

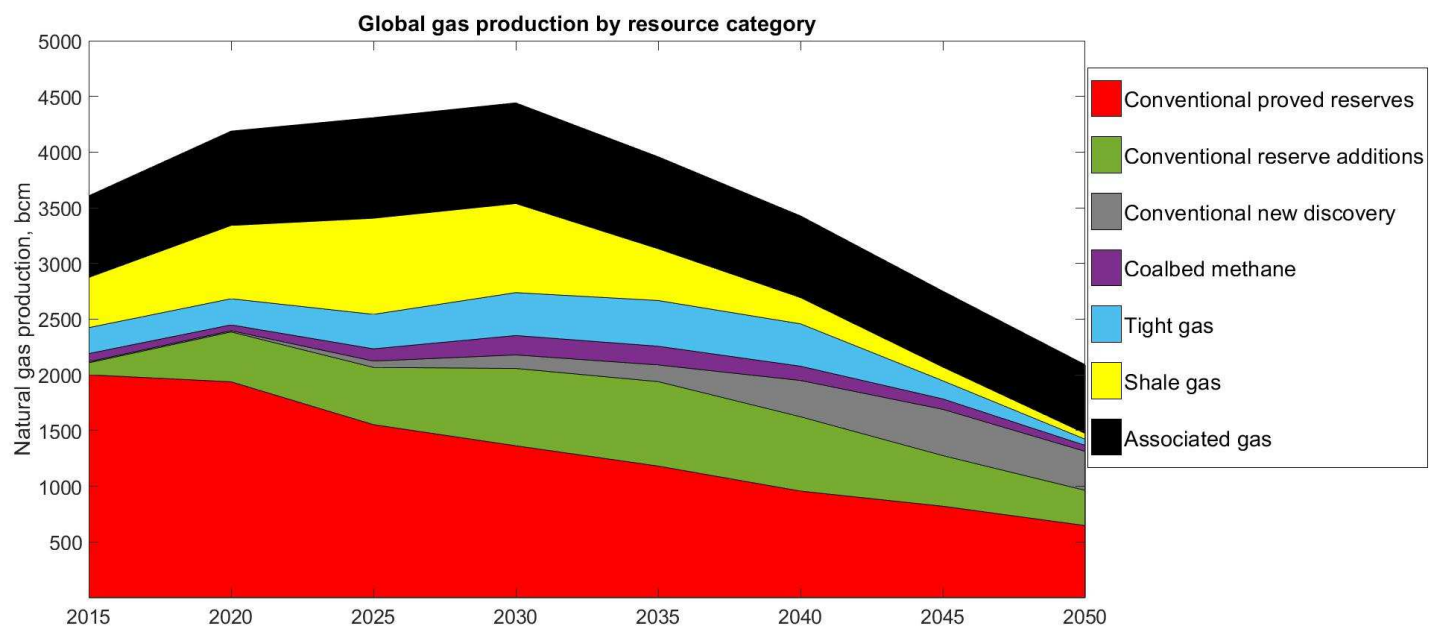

Figure 12. Global gas production by a) region and b) resource category

Figure 13 (a) and (b) shows the cumulative (2020-2050) differences in production between the central scenario and the low ('Lo' $-10^{\text {th }}$ percentile methane leakage rate) and high (' $\mathrm{Hi}^{\prime}$ $-90^{\text {th }}$ percentile methane leakage rate) sensitivity analysis which varied the methane leakage rate as shown in Table 7. Figure 13 shows that the most sensitive regions to changes in the leakage rate of methane are those with large resource bases of unconventional natural gas. . Therefore for any company with exposure to unconventional gas assets, the deployment of monitoring equipment and rapid mitigation of any leakage is fundamental to the supply of gas from shale and tight formations. In the absence of country-level regulation to enforce these measures, if the major fossil fuel companies who have declared net-zero ambitions (BP, Shell, Total, ENI) are going to meet these targets, then unilateral or industrywide environmental regulation and practices will be key. For reference, we used the same method for calculating regional variations in Figure 13 as in Figure 9: by subtracting cumulative production in the central scenario from cumulative production in the high and low methane leakage sensitivities, respectively. As with oil, any regional decrease (increase) in cumulative production signifies that production is lower (higher) in the low/high sensitivity compared to the central scenario. 
a)

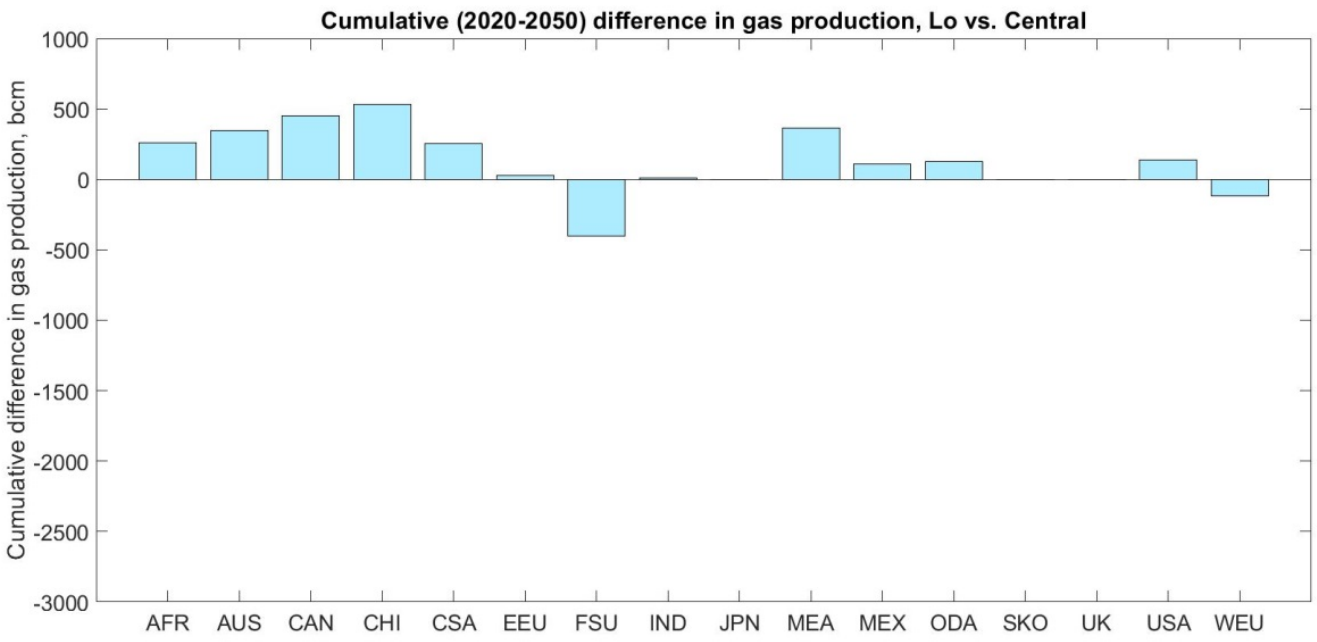

b)

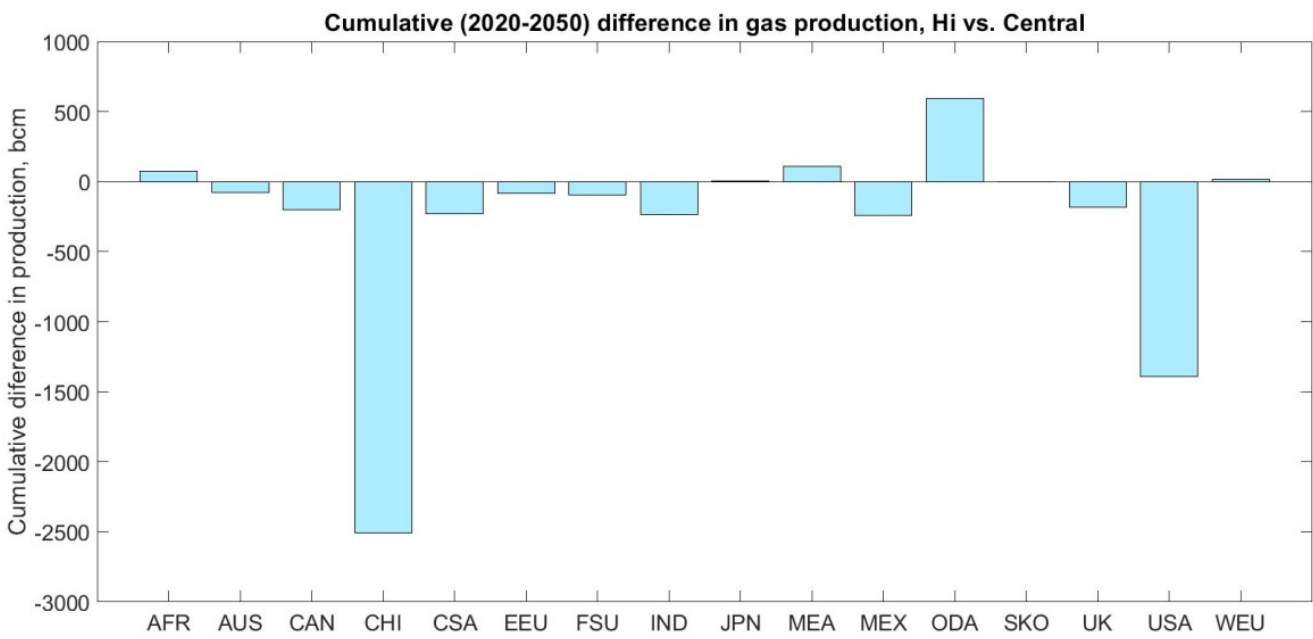

Figure 13. Cumulative (2020-2050) production change between the central carbon intensity value for gas and the a) low and b) high cases

For natural gas, the importance of minimising fugitive leakage of methane from supply chains was reflected in Figure 13a,b. As would be expected, regions with a large unconventional resource base were particularly sensitive to the lower and higher sensitivities in controlling fugitive leakage rates; the largest (negative) impact on gas supply between the high and central methane leakage rates were found in the United States and China. Particularly in the case of China, higher fugitive rates of methane emissions result in higher import dependency; a diverse range of exporters supply this natural gas, with the Other Developing Asia region utilising more of its conventional resource base via export to China (driving some of the increase in supply between the high and central sensitivity seen in Figure 13b). 
Table 11. Percentage share of unconventional gas production in 2035 of total global gas supply

\begin{tabular}{|lcccc|} 
Sensitivity & $\begin{array}{l}\text { Gas leakage } \\
\text { rate, \% }\end{array}$ & $\begin{array}{l}\text { Share of global gas supply } \\
\text { from unconventional } \\
\text { assets (2025), \% }\end{array}$ & $\begin{array}{l}\text { Share of global gas supply } \\
\text { from unconventional } \\
\text { assets }(2035), \%\end{array}$ & $\begin{array}{l}\text { Share of global gas supply } \\
\text { from unconventional } \\
\text { assets (2050), \% }\end{array}$ \\
\hline Low & 0.6 & 31 & 31 & 25 \\
\hline Central & 2.5 & 30 & 26 & 8 \\
\hline High & 6.2 & 26 & 10 & 2 \\
\hline
\end{tabular}

Utilising the region-/resource-specific insights from

Figure 12 and Figure 13, this section provides some more disaggregated insights into company-level exposure to regions and/or resource categories most sensitive to the carbon intensity sensitivities conducted in the previous section. Firstly, Table $12^{8}$ lays out the reserve and resource base for different categories of natural gas in each region (Welsby, forthcoming; McGlade, 2013). Table 10 then explores the level of un-burnable carbon from each region and resource sub-category in the below $2^{\circ} \mathrm{C}$ sensitivities. In addition to this, these insights are then used to provide indications of national and international oil companies with potentially large exposure to variations in carbon intensities (i.e. large changes in the percentage of the resource base which should be considered un-burnable).

Table 12. Reserve and resource availability for different categories of natural gas from $2015^{9}$

\begin{tabular}{|c|c|c|c|c|c|c|}
\hline Region & $\begin{array}{l}\text { Proved non- } \\
\text { associated } \\
\text { conventional } \\
\text { reserves, tcm }\end{array}$ & $\begin{array}{l}\text { Proved non- } \\
\text { associated } \\
\text { conventional } \\
\text { reserve } \\
\text { additions, tcm }\end{array}$ & $\begin{array}{l}\text { Undiscovered } \\
\text { non-associated } \\
\text { conventional } \\
\text { resources, tcm }\end{array}$ & $\begin{array}{l}\text { Shale } \\
\text { technically } \\
\text { recoverable } \\
\text { resources, } \\
\text { tcm }\end{array}$ & $\begin{array}{l}\text { Tight } \\
\text { technically } \\
\text { recoverable } \\
\text { resources, } \\
\text { tcm }\end{array}$ & $\begin{array}{l}\text { CBM } \\
\text { technically } \\
\text { recoverable } \\
\text { resources, } \\
\text { tcm }\end{array}$ \\
\hline $\begin{array}{l}\text { AFR } \\
\text { (Other) }\end{array}$ & 1.8 & 2.8 & 14.3 & 5.2 & 2.3 & 0.4 \\
\hline AUS & 2.5 & 2.1 & 6.1 & 10.5 & 4.3 & 7.0 \\
\hline CAN & 0.8 & 0.6 & 0.6 & 7.5 & 9.5 & 1.5 \\
\hline $\mathrm{CHI}$ & 1.7 & 2.3 & 1.9 & 28.3 & 11.0 & 8.9 \\
\hline EEU & 0.3 & 0.3 & 0.2 & 4.8 & 0.2 & 0.2 \\
\hline FSU & 37.3 & 31.1 & 9.1 & 8.9 & 5.3 & 14.4 \\
\hline IND & 1.1 & 1.1 & 1.8 & 3.0 & 0.0 & 2.4 \\
\hline $\begin{array}{l}\text { MEA } \\
\text { (Other) }\end{array}$ & 0.8 & 0.7 & 2.9 & 0.6 & 0.5 & 0.3 \\
\hline $\begin{array}{l}\text { MEA } \\
\text { (Opec) }\end{array}$ & 46.8 & 7.6 & 5.6 & 5.5 & 2.4 & 0.0 \\
\hline MEX & 0.2 & 0.2 & 1.1 & 9.6 & 0.0 & 0.0 \\
\hline ODA & 4.9 & 7.0 & 9.4 & 2.3 & 2.0 & 3.4 \\
\hline
\end{tabular}

\footnotetext{
${ }^{8}$ This is a tabular representation of the x-axis (i.e. resource availability) in Figure 7 (a) and (b)

${ }^{9}$ For the most part this is the central output from probabilistic analysis conducted by Welsby (forthcoming) and McGlade (2013)
} 
Table 13 below shows the percentage of each resource category in each region (Table 12) which remains in the ground out to 2050 in the below $2^{\circ} \mathrm{C}$ scenario (i.e. resource base minus cumulative production, divided by the resource base). The ranges should be interpreted as follows, where the value on the left of the range denotes the low carbon intensity case and on the right, the high carbon intensity case. It shows in general that under the high carbon intensity assumptions, less conventional resource is left unused while more unconventional is unused. Large variations ( $>20 \%$ ) are shown in blue bold. Where only a single value is shown, this means no (or very limited) variation.

Table 13. Unburnable gas reserves and resource volumes across the carbon intensity (methane leakage) sensitivity cases. The first number in the range constitutes the low case and the second number the high case. Where there is a single value, this means that the change in carbon intensity has had marginal or no impact. Blue number denote where the largest changes have occurred.

\begin{tabular}{|c|c|c|c|c|c|c|}
\hline Region & Reserves, \% & $\begin{array}{l}\text { Reserve } \\
\text { additions, \% }\end{array}$ & $\begin{array}{l}\text { Undiscovered } \\
\text { conventional } \\
\text { resources, \% }\end{array}$ & Shale, \% & Tight gas, $\%$ & $\begin{array}{l}\text { Coal Bed } \\
\text { Methane, \% }\end{array}$ \\
\hline $\begin{array}{l}\text { AFR } \\
\text { (Other) }\end{array}$ & 41 & $54-53$ & $98-92$ & 100 & $59-100$ & 100 \\
\hline $\begin{array}{l}\text { AFR } \\
\text { (Opec) }\end{array}$ & 42 & 100 & 100 & 100 & 100 & 100 \\
\hline AUS & $74-52$ & $89-47$ & $100-74$ & $77-100$ & $92-100$ & $86-98$ \\
\hline CAN & $79-38$ & $100-51$ & $100-92$ & 100 & $69-84$ & $100-99$ \\
\hline $\mathrm{CHI}$ & $36-26$ & $53-38$ & $96-67$ & $99-100$ & $53-86$ & $96-100$ \\
\hline $\begin{array}{l}\text { CSA } \\
\text { (Other) }\end{array}$ & 55 & $98-49$ & $100-99$ & $97-100$ & $70-99$ & $58-100$ \\
\hline $\begin{array}{l}\text { CSA } \\
\text { (Opec) }\end{array}$ & $75-70$ & 100 & 100 & $81-100$ & 100 & 100 \\
\hline EEU & 50 & $70-76$ & $96-94$ & $98-100$ & 100 & $26-70$ \\
\hline FSU & 76 & $80-73$ & $99-100$ & 100 & $77-100$ & 100 \\
\hline IND & $29-18$ & $20-17$ & $45-42$ & $63-100$ & 100 & $54-56$ \\
\hline $\begin{array}{l}\text { MEA } \\
\text { (Other) }\end{array}$ & 64 & 100 & 100 & 100 & 100 & $77-100$ \\
\hline $\begin{array}{l}\text { MEA } \\
\text { (Opec) }\end{array}$ & 66 & 100 & 100 & 100 & 100 & 100 \\
\hline MEX & $47-43$ & $76-68$ & $100-99$ & $90-95$ & 100 & 35 \\
\hline ODA & $39-36$ & 53 & $76-65$ & 100 & $52-100$ & 10330 \\
\hline UK & 58 & 56 & $56-60$ & $65-94$ & 100 & 70 \\
\hline USA & $53-3$ & $100-98$ & 100 & $58-64$ & $96-97$ & $67-98$ \\
\hline WEU & 53 & 49 & $94-76$ & 100 & $81-100$ & $41-96$ \\
\hline Global & $65-63$ & $79-71$ & $95-88$ & $90-93$ & $78-94$ & $90-97$ \\
\hline
\end{tabular}

Using Table 12(a) and (b), and the more detailed insights in Table 13, Table 14 identifies companies holding undeveloped natural gas assets across different geological categories in regions where the outputs from the carbon intensity sensitivities suggest significant exposure. 
Table 14. Undeveloped natural gas assets by companies at risk due to high carbon intensity by company

\begin{tabular}{|c|c|c|c|c|}
\hline Region & $\begin{array}{l}\text { Company (Resources, } \\
\operatorname{tcm}^{10} \text { ) }\end{array}$ & $\begin{array}{l}\text { Resource category } \\
\text { (carbon intensity } \\
\text { sensitivity) where } \\
\text { exposure is } \\
\text { greatest }\end{array}$ & $\begin{array}{l}\text { Reason why exposure } \\
\text { increases (if applicable) }\end{array}$ & Key assets \\
\hline Africa_NOPEC & $\begin{array}{l}\text { ENI, Total, Anadarko } \\
(1.4)\end{array}$ & Reserve additions & $\begin{array}{l}\text { Significant proportions } \\
\text { of undeveloped field } \\
\text { discoveries remain } \\
\text { unburned }\end{array}$ & $\begin{array}{l}\text { Mozambique offshore } \\
\text { (Area 1, Area 4) }\end{array}$ \\
\hline Africa_OPEC & $\begin{array}{l}\text { Sonatrach, Nigerian } \\
\text { National Petroleum } \\
\text { Corporation, Hess Oil, } \\
\text { Libyan National Oil } \\
\text { Corporation, Shell } \\
(0.07) \text {, Total }(0.15)\end{array}$ & $\begin{array}{l}\text { Reserve additions } \\
\text { (all sensitivities) }\end{array}$ & $\begin{array}{l}\text { Sufficient proved } \\
\text { reserves (along with } \\
\text { higher utilisation of } \\
\text { associated gas) to meet } \\
\text { domestic demand. }\end{array}$ & $\begin{array}{l}\text { Nnwa Doro, Bosi, Akri- } \\
\text { Oguta, Ubie-Oshi, Afuo- } \\
\text { Ogbainbri, Assa-North, } \\
\text { Ohaji South (Nigeria) }\end{array}$ \\
\hline Australia & $\begin{array}{l}\text { Exxon }(0.2) \text {, Shell }(0.2) \text {, } \\
\text { Chevron }(0.3)\end{array}$ & $\begin{array}{l}\text { Reserve additions } \\
\text { (low) }\end{array}$ & $\begin{array}{l}\text { More of the production } \\
\text { share can be taken up } \\
\text { from unconventional } \\
\text { natural gas when } \\
\text { methane leakage is kept } \\
\text { to the lower sensitivity } \\
(\sim 0.6 \%)\end{array}$ & $\begin{array}{l}\text { Gorgon gas project } \\
\text { including as of yet } \\
\text { undeveloped fields } \\
\text { further offshore } \\
\text { (Chevron, Exxon, Shell); } \\
\text { undeveloped Browse } \\
\text { LNG (Shell, BP) }\end{array}$ \\
\hline China & $\begin{array}{l}\text { Total (0.1), CNPC, } \\
\text { CNOOC }\end{array}$ & Tight gas (high) & $\begin{array}{l}\text { If methane leakage is } \\
\text { not controlled } \sim 4 \mathrm{tcm} \\
\text { additional tight gas } \\
\text { becomes unburnable }\end{array}$ & $\begin{array}{l}\text { Sulige gas complex, } \\
\text { Hechuan, Xinchang gas } \\
\text { field }\end{array}$ \\
\hline $\begin{array}{l}\text { Central and } \\
\text { South } \\
\text { America }\end{array}$ & $\begin{array}{l}\text { YPF, Shell, Exxon, } \\
\text { Conoco Phillips ( } 45 \text { and } \\
50 \% \text { stakes in two } \\
\text { blocks of Vaca } \\
\text { Muerta), Petrobras }\end{array}$ & $\begin{array}{l}\text { Unconventional gas } \\
\text { (high), reserve } \\
\text { additions (high) }\end{array}$ & $\begin{array}{l}\text { High methane leakage } \\
\text { leads to model not } \\
\text { developing any of South } \\
\text { America's shale } \\
\text { resources (e.g. Vaca } \\
\text { Muerta). In this case, } \\
\text { reserve additions are } \\
\text { exploited more } \\
\text { intensely (represented } \\
\text { by the lower percentage } \\
\text { of reserve additions } \\
\text { unburned compared to } \\
\text { the low and central } \\
\text { cases) }\end{array}$ & $\begin{array}{l}\text { Vaca Muerta, pre-salt } \\
\text { deposits including } \\
\text { Carcara, Mero, Block } \\
\text { BM-C-33 (Brazil) }\end{array}$ \\
\hline $\begin{array}{l}\text { Former } \\
\text { Soviet Union }\end{array}$ & Gazprom $\left(10-11^{11}\right)$ & $\begin{array}{l}\text { Reserve additions } \\
\text { (low) }\end{array}$ & $\begin{array}{l}\text { If methane leakage from } \\
\text { unconventional gas is } \\
\text { kept to the lower } \\
\text { bound, an additional } 3 \\
\text { tcm of potential } \\
\text { additions in FSU remain } \\
\text { unburned }\end{array}$ & $\begin{array}{l}\text { Shtokman, } \\
\text { Arkticheskoye, } \\
\text { Leningradskoye }\end{array}$ \\
\hline $\begin{array}{l}\text { Middle } \\
\text { East_OPEC }\end{array}$ & $\begin{array}{l}\text { National Iranian Oil } \\
\text { Company, Aramco, } \\
\text { ADNOC }\end{array}$ & Proved reserves & $\begin{array}{l}\text { Demand reduction post- } \\
2030 \text { means political } \\
\text { decision to develop high } \\
\text { cost sour gas resources } \\
\text { is high-risk }\end{array}$ & $\begin{array}{l}\text { Shah gas development } \\
\text { (UAE), Haradh fields } \\
\text { (ultra-deep, ultra-sour) } \\
\text { (Saudi Arabia), South } \\
\text { Pars, Kish (Iran) }\end{array}$ \\
\hline Mexico & PEMEX & Shale (high) & $\begin{array}{l}\text { Additional } 0.5 \mathrm{tcm} \text { of } \\
\text { shale gas becomes } \\
\text { unburnable }\end{array}$ & Burgos Basin \\
\hline
\end{tabular}




\begin{tabular}{|c|c|c|c|c|}
\hline $\begin{array}{l}\text { Other } \\
\text { Developing } \\
\text { Asia }\end{array}$ & $\begin{array}{l}\text { ConocoPhillips, Shell, } \\
\text { Chevron, Pertamina, } \\
\text { Petronas }\end{array}$ & $\begin{array}{l}\text { Undeveloped } \\
\text { conventional } \\
\text { resources (all } \\
\text { sensitivities) }\end{array}$ & $\begin{array}{l}\text { Risk lies with isolated } \\
\text { and challenging-to- } \\
\text { develop fields }\end{array}$ & $\begin{array}{l}\text { Natuna (Indonesia), } \\
\text { Gula (Indonesia), Abadi } \\
\text { (Indonesia), Block SK- } \\
320 \text { (Malaysia) }\end{array}$ \\
\hline United States & $\begin{array}{l}\text { Exxon (through } \\
\text { affiliate XTO Energy } \\
\text { large presence in } \\
\text { Marcellus shale play } \\
\text { and Permian tight oil } \\
\text { (and therefore } \\
\text { associated gas)), BP } \\
\text { (through BPX), } \\
\text { Chesapeake, Cabot Oil }\end{array}$ & $\begin{array}{l}\text { Unconventional } \\
\text { (shale, tight and } \\
\text { CBM), proved } \\
\text { reserves (high) }\end{array}$ & $\begin{array}{l}\text { In the case where } \\
\text { methane leakage is high, } \\
\text { far more of the } \\
\text { conventional reserve } \\
\text { base is utilised including } \\
\text { Gulf of Mexico which } \\
\text { has its own specific set } \\
\text { of operational and } \\
\text { financial risks (deep- } \\
\text { water, high reservoir } \\
\text { depth) }\end{array}$ & $\begin{array}{l}\text { Marcellus, Barnett, } \\
\text { Permian shale plays; Big } \\
\text { Foot Sub-salt, St. Malo } \\
\text { (Gulf of Mexico) }\end{array}$ \\
\hline $\begin{array}{l}\text { Western } \\
\text { Europe }\end{array}$ & $\begin{array}{l}\text { Equinor (0.3), Shell } \\
(0.1) \text {, Exxon (0.07) }\end{array}$ & $\begin{array}{l}\text { Reserves and } \\
\text { reserve additions } \\
\text { (all sensitivities) }\end{array}$ & $\begin{array}{l}\text { Relatively high cost of } \\
\text { European production } \\
\text { compared to other } \\
\text { producers; gas demand } \\
\text { destruction in Europe if } \\
<2^{\circ} \mathrm{C} \text { is to be met (e.g. } \\
\text { decarbonisation of } \\
\text { heating) }\end{array}$ & $\begin{array}{l}\text { Groningen (Shell and } \\
\text { Exxon), Troll gas field, } \\
\text { Lavrans (undeveloped } \\
\text { and high } \mathrm{H}_{2} \mathrm{~S} \text { ) }\end{array}$ \\
\hline
\end{tabular}

*Due to the fact there are thousands of operators, some of whom are currently being bought out by major oil companies, it is more difficult to assign company level assets in unconventional plays.

\subsection{Modelling summary}

Key points from the modelling analysis include -

- There is a wide variation in the carbon intensity of different oil and gas fields within resource categories, and between categories. The results reflect a wide review of the publically available information.

- In particular, higher values reflect the significantly higher carbon intensity of unconventional oil, mainly due to fuel inputs required to further process the extracted oil, and the higher methane leakage rates associated with unconventional gas.

- The reviewed information has been incorporated into TIAM-UCL, providing a much improved representation and allowing for uncertainty analysis to be conducted in the form of the low, central and high carbon intensity $(\mathrm{Cl})$ sensitivities.

- As expected, under a climate policy run, the variation in carbon intensity does not change the aggregated global results significantly, particularly for oil, due to the much stronger drivers of field economics and demand reduction for fossil fuels. However, it is clear that higher $\mathrm{Cl}$ makes unconventional oil even less attractive.

- Particularly for unconventional natural gas, the results show the importance of keeping fugitive emissions to a minimum; the role of regulation can be a key driver of this (monitoring of equipment, mitigation of leakage, and effective enforcement in case of non-compliance). In the absence of regulation from national governments, oil and gas companies should drive this mitigation as an industry.

- Continued exploration in high risk areas is generally incompatible with meeting a $2^{\circ} \mathrm{C}$ target, and particularly reaching below $-2^{\circ} \mathrm{C}$. In the natural gas sensitivities, at least 
$89 \%$ of 'undiscovered' conventional natural gas remains unused and if methane leakage rates are not controlled, then $>90 \%$ of unconventional deposits stay in the ground.

- The aggregation of TIAM-UCL loses some of the variation that one might see within region; further work using field level models would help explore this further.

However, some insights are provided as to what regional reserves / resources may be at increased risk, and to some extent, which companies own them. 


\section{Future prospects and transition strategies}

As shown in the previous section, Paris Agreement-aligned goals would see large declines in the production of oil and gas, as demand shifts to low carbon forms of energy. This implies that absolute levels of scope 3 emissions need to be seriously considered by the producers, with the decline indicative of the risks to their core business. The modelling also shows the risk of holding specific types of oil and gas that would not be exploited under such climate ambition. This is due to both their higher carbon intensity and their economics of production (relative to other more cost-effective resources in a declining market). Finally, it is also worth highlighting the implications of high carbon intensity for gas production, driven by methane leakage, and how this impacts the levels of production across different regions.

The next question is: are oil and gas companies responding to the implications of the Paris Agreement goals? And are these strategies sufficient? We start by focusing on the current strategies of both IOCs and NOCs.

\subsection{International oil companies (IOCs)}

IOCs are aware of the new reality facing the sector and have adopted different strategies to ensuring the sustainability and in some cases longevity of their business. As shown in Table 15 , three different groups of strategy have emerged amongst the oil and gas majors.

Table 15. Strategies adopted by oil majors

\begin{tabular}{|c|c|c|c|}
\hline & Group & Description & Company examples \\
\hline 1 & $\begin{array}{l}\text { "Last man } \\
\text { standing" }\end{array}$ & $\begin{array}{l}\text { - Most US majors' approach } \\
\text { - Strategy based on companies' core and heritage, } \\
\text { low cost approach } \\
\text { - Focus include 1) short term cycle unconventional } \\
\text { and 2) high return conventional }\end{array}$ & $\begin{array}{l}\text { ExxonMobil } \\
\text { Chevron } \\
\text { ConocoPhillips }\end{array}$ \\
\hline 2 & “In Transition" & $\begin{array}{l}\text { - } \quad \text { Balancing out portfolio with investor pressure } \\
\text { - Streamlining oil \& gas portfolio, exiting high cost / } \\
\text { high carbon intensity activities } \\
\text { - Increasing investment in new energy }\end{array}$ & Equinor \\
\hline 3 & "Transformation" & $\begin{array}{l}\text { - Major strategic shift, from 'oil \& gas' to 'energy' } \\
\text { - High and strategic investment towards low energy } \\
\text { - More natural gas focus in upstream portfolio } \\
\text { - } \quad \text { Long term focus on energy transition (ET) related } \\
\text { R\&D (ie hydrogen CCS) }\end{array}$ & $\begin{array}{l}\text { BP } \\
\text { Total } \\
\text { Shell } \\
\text { ENI }\end{array}$ \\
\hline
\end{tabular}

Source: Authors

It is the 'Transformation' group who have adopted an apparent strategy to diversify their businesses away from oil and gas, whilst the US producers, in the 'Last man standing' group, appear to be focused on gaining as much value as possible in the short term with limited strategic view of the longer term. In terms of the net zero targets of the 'Transformation' group, the details on the exact pathways are yet to be disclosed. At this stage it is unclear how consistent the announced net zero plans will be with the ambition set out in the Paris 
Agreement, and the role for offsets (a highly contentious approach adopted by the aviation industry). Figure 14 provides a summary by the IEA showing that shifts in business strategy vary considerably by company (IEA, 2020a), as shown in Table 15.

\begin{tabular}{|c|c|c|c|c|c|c|c|c|c|c|c|}
\hline \multirow[t]{2}{*}{ Company } & \multicolumn{3}{|c|}{$\begin{array}{l}\text { Enhancing traditional oil and } \\
\text { gas operations }\end{array}$} & \multicolumn{2}{|c|}{$\begin{array}{l}\text { Deploying } \\
\text { CCus }\end{array}$} & \multicolumn{2}{|c|}{$\begin{array}{l}\text { Supplying liquids } \\
\text { and gases for } \\
\text { energy } \\
\text { transitions } \\
\end{array}$} & \multicolumn{4}{|c|}{ Transitioning from fuel to "energy companies" } \\
\hline & $\begin{array}{l}\text { Reducing } \\
\text { methane } \\
\text { emissions }\end{array}$ & $\begin{array}{l}\text { Reducing } \\
\mathrm{CO}_{2} \\
\text { emissions }\end{array}$ & $\begin{array}{l}\text { Sourcing } \\
\text { renewable } \\
\text { power }\end{array}$ & $\begin{array}{l}\text { For } \\
\text { centralised } \\
\text { emissions }\end{array}$ & $\begin{array}{l}\text { For } \\
\text { EOR }\end{array}$ & $\begin{array}{l}\text { Low- } \\
\text { carbon } \\
\text { gases }\end{array}$ & $\begin{array}{l}\text { Advanced } \\
\text { biofuels }\end{array}$ & $\begin{array}{l}\text { Solar PV } \\
\text { and wind } \\
\text { generation }\end{array}$ & $\begin{array}{c}\text { Other } \\
\text { power } \\
\text { generation }\end{array}$ & $\begin{array}{c}\text { Electricity } \\
\text { distribution/retail }\end{array}$ & $\begin{array}{l}\text { Electrified } \\
\text { services I } \\
\text { efficiency }\end{array}$ \\
\hline $\mathrm{BP}$ & - & - & - & D & D & - & - & - & D & D & - \\
\hline Chevron & $\bullet$ & (1) & - & $\bullet$ & D & D & (1) & 0 & O & 0 & D \\
\hline Eni & - & (1) & - & D & D & (1) & - & - & - & - & D \\
\hline ExxonMobil & $\bullet$ & D & - & - & 0 & D & 0 & 0 & 0 & 0 & 0 \\
\hline Shell & - & - & - & - & 0 & - & 0 & - & - & - & - \\
\hline Total & $\bullet$ & - & - & 0 & 0 & - & - & - & - & - & - \\
\hline CNPC & (1) & 0 & D & 0 & - & 0 & (1) & - & 0 & 0 & 0 \\
\hline Equinor & - & - & ○ & ○ & D & D & (1) & - & 0 & D & D \\
\hline Petrobras & D & D & - & - & - & - & D & D & - & D & 0 \\
\hline Repsol & - & - & 0 & D & 0 & D & D & - & - & - & D \\
\hline
\end{tabular}

Figure 14. Shifts in strategy across major oil companies. Full circle = growth area supported by observed strategic investments (e.g. M\&A) and/or capital/operational expenditures in commercial-scale activities; half circle = announced strategy and/or minor investments, venture capital and/or research and development $(R \& D)$ spending; empty circle= limited evidence of investment activity. Source: IEA (2020a)

\subsection{National oil companies (NOCs)}

NOCs are stewards of national hydrocarbon resources on behalf of their host governments, with legally defined roles in upstream development, which can also extend to the mid and downstream. States' dependence on oil \& gas export revenues varies by country, however such revenues tend to make a major contribution to public spending, infrastructure development and overall employment. The Middle East is home to the world's largest NOCs, which includes Saudi Aramco, Qatar Petroleum, ADNOC (UAE), and National Iranian Oil Company. Outside the Middle East, Sonatrach (Algeria), Rosneft (Russia), Petrobras (Brazil), PDVSA (Venezuela) and the Nigeria National Petroleum Company are other NOCs with major operations.

INOCs are NOCs that operate internationally with operations beyond their host countries. Examples include Gazprom (Russia), China National Offshore Oil Corporation (CNOOC), Sinopec (China) and India's Oil and Natural Gas Corporation (ONGC). The oil Majors, which are the seven largest integrated oil \& gas companies, attract most of the attention due their high influence on the sector. However they represent only $12 \%$ of oil \& gas reserves and $15 \%$ of production, and $10 \%$ of estimated emissions from industry operations (IEA, 2020a). National Oil Companies (NOC), majority owned or fully owned by governments, account for over half of global production and hold approximately two-thirds of reserves.

Oil

NOCs control two-thirds of the world's proven oil reserves (conventional and unconventional). In the Middle East and Latin America, the majority of reserves are held by 
NOCs. In Russia, the majority of reserves are held by private and 'independent' companies, although state-owned companies are increasing their share. In the United States, the role is taken by private companies. NOCs also generally control the reserves with the lowest average development and production costs, with slower decline rates requiring less capital spending to maintain production (IEA, 2020a).

Although NOCs own a majority of oil reserves, they only produce $45 \%$ of total oil. This is partly due to OPEC market management and host government pressures on these organisations. From a development and production costs perspective, broadly speaking NOC-owned fields represent the lowest average costs with slower decline rates. This translates to NOC investment into upstream projects being disproportionately low compared to the size of their reserves. By contrast, IOCs invest and operate projects with higher costs and higher decline rates, such as deepwater and tight oil fields (IEA, 2020a).

The profiles of most NOCs, with the exception of Iraq and Venezuela, tend to therefore produce less emissions on average when compared to major international oil companies and more broadly the overall industry. Figure 15 below illustrates this point. This is not in small part due to the giant and less carbon-intensive fields of Saudi Arabia.

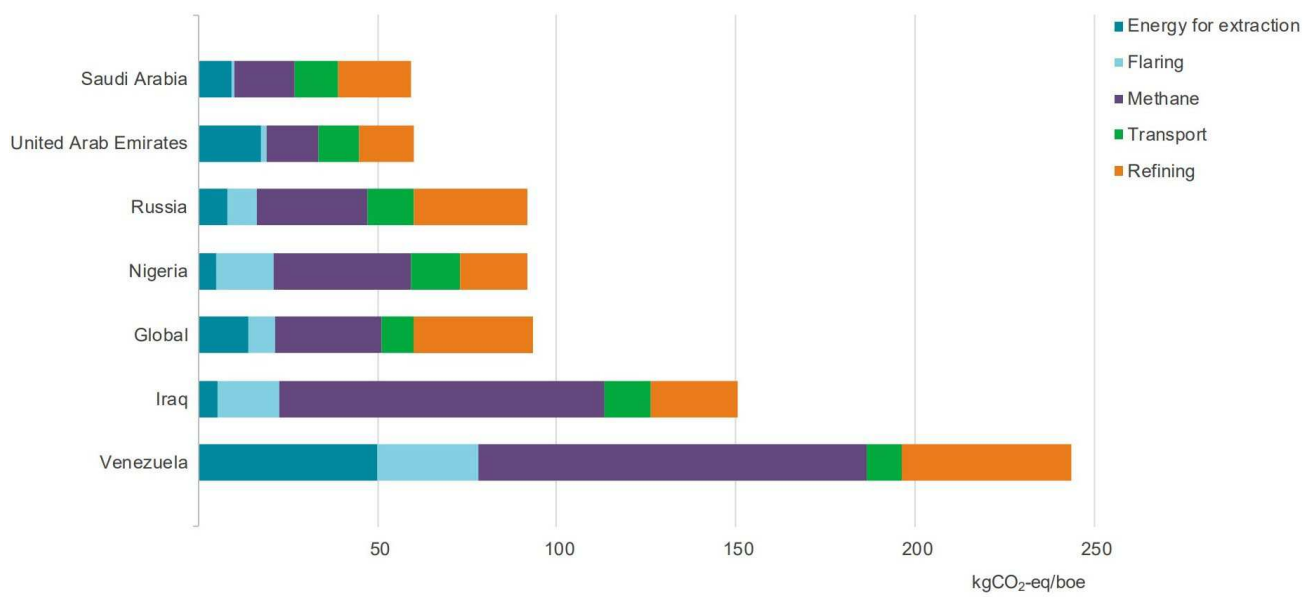

Figure 15. Average GHG emissions intensity of oil across selected countries, 2018. Source: IEA (2020a)

\section{Natural Gas}

The shares of natural gas reserves are more evenly distributed between NOCs and IOCs for natural gas, as compared to oil. Similar to oil, reserve levels of NOCs are larger than their share of production. Figure 16 provides a breakdown of ownership of oil \& gas reserves, production and upstream investment by company type in 2019. 


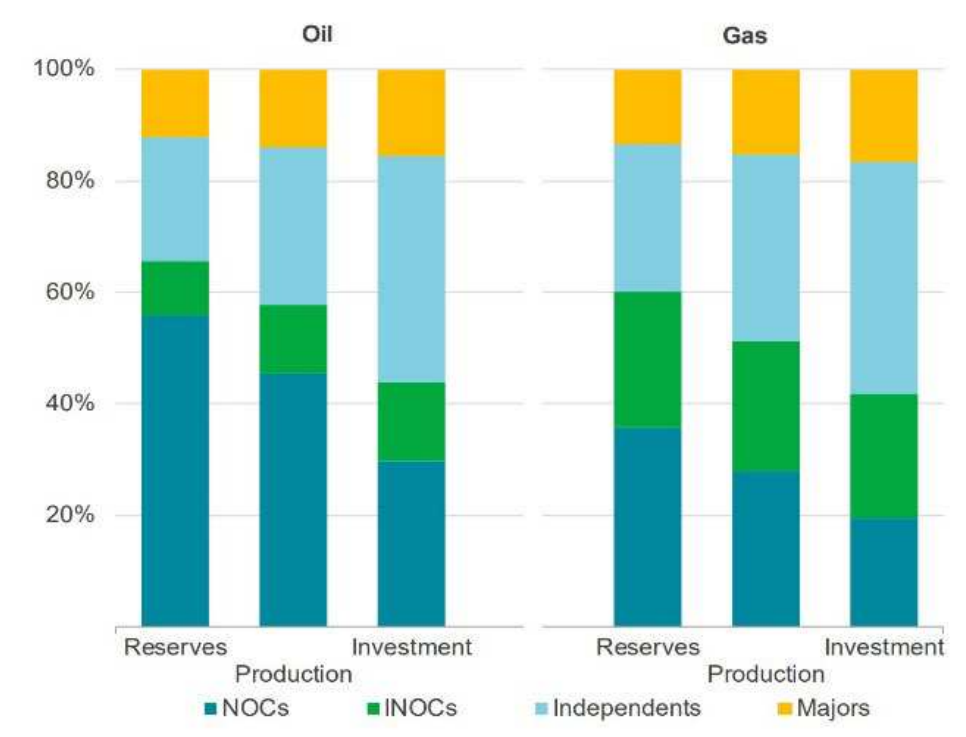

Figure 16. Ownership of oil and gas reserves, production and upstream investment by company type, 2018. Source: IEA (2020). Majors refers to seven large integrated oil \& gas companies: BP, Chevron, ExxonMobil, Shell, Total, ConocoPhillips and Eni.

\section{NOC and INOC approaches to transition}

NOCs, and to a lesser extent INOCs, are taking a more conservative approach to the lowcarbon energy transition, being constrained by structural economic issues (transfer pricing, subsidies, the profile of domestic resources) and the policies of their host governments. According to a survey from IHS Markit (2019), 89\% of global integrated oil companies use and disclose scenario-based climate strategies, but only $6 \%$ of NOCs

NOCs that represent a major portion of the country's revenue have additional responsibility as their countries' development relies heavily on the associated oil \& gas income (Figure 17). While this has discouraged the development for some of the Asian based, or smaller NOCs, others, mainly the larger Middle East NOCs, which play a larger role in total exports, have attempted to go beyond striving towards more efficient operations, to being more proactive in preparing for the energy transition by investing in decarbonisation methods such as CCUS and hydrogen. Aramco launched a venture capital fund investing in new energy applications and technologies, and has shown a strong interest in cooperating with Japan on CCS and Hydrogen development. Kuwait Petroleum Corporation, ADNOC and Qatar Petroleum (QP) have been involved in a series of low-carbon initiatives in recent years, including the establishment of MASDAR city and fund in Abu Dhabi, and the award of an $800 \mathrm{MW}$ solar plant by QP.

However, none of the major NOCs have been given a clear mandate by their governments to manage the transition, instead they are generally mandated to focus on managing efficient operations to deliver much needed strong financial returns for the State. In the long term, the social contract which dictates how these companies operate will have to be revisited, and potentially painful measures such as the phasing out of subsidies and overall price reform will have to be taken. From a governance perspective, NOCs will have to fundamentally restructure, or, alternatively, separate spin off companies could be established to focus on the low-carbon portfolio, leaving traditional fossil fuels to heritage 
NOCs. Until then, NOCs are expected to continue to produce and export their domestic resources as much as possible.

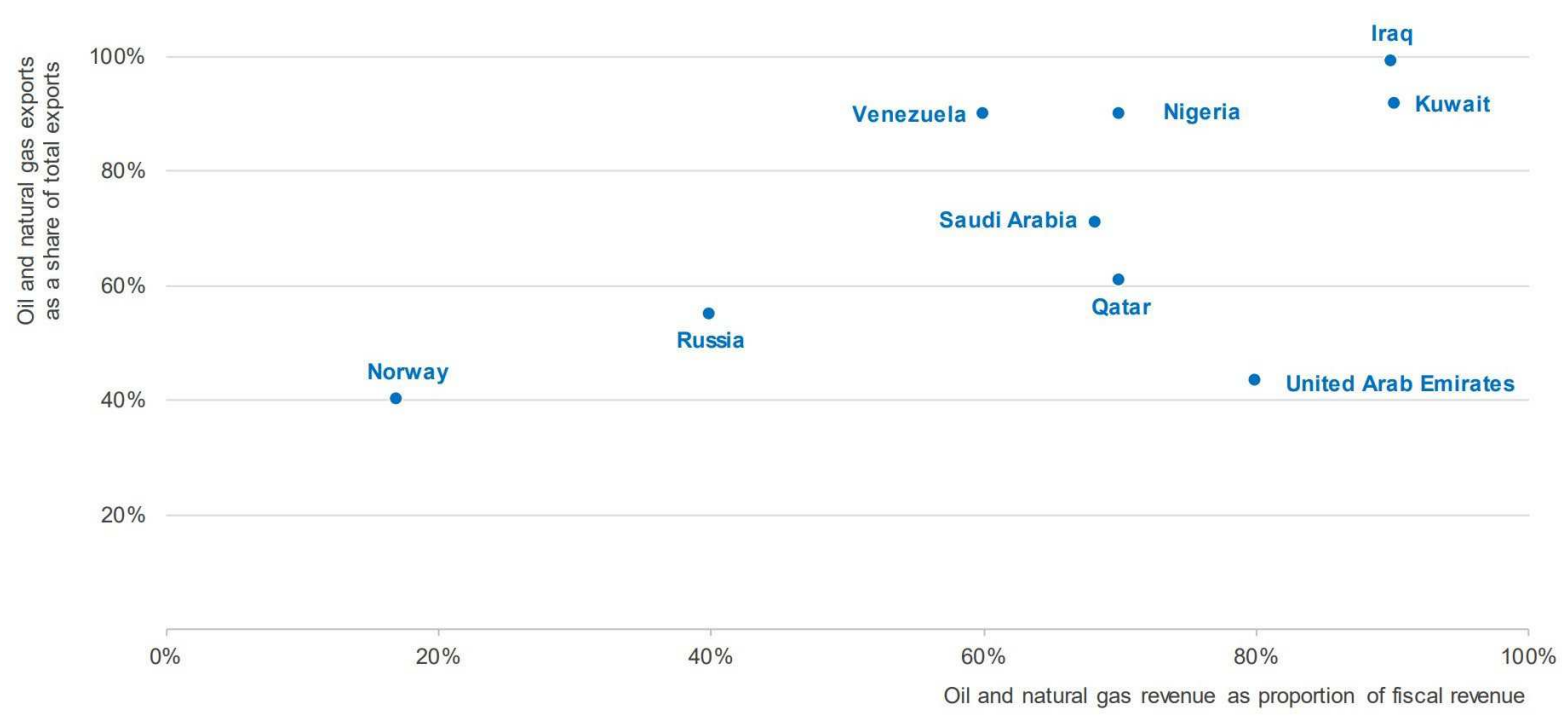

Figure 17. Oil and gas as a share of total exports and as a share of total fiscal revenues in selected countries, 2017. Source: IEA (2020a)

\subsection{Insights from the research}

There are some key insights that we can draw from this research that are pertinent to the future strategies of the oil and gas sector:

1. Narrow scope $1 \& 2$ carbon intensity metrics alone are insufficient for company reporting on progress towards climate goals. For IOCs, the carbon intensity of the final product also needs to be considered, given that it is subject to increased demand side policy e.g. in relation to carbon pricing, ICE sale bans etc.

Furthermore, climate targets are ultimately expressed in absolute terms. Therefore, relative improvements as measured by carbon intensity metrics are insufficient to guide progress towards net-zero emissions. As shown by the modelling, there is a significant decline in the levels of production permitted under climate targets by 2050.

For longer term diversification, metrics that account for scope 3 emissions will be important to consider, to monitor the transformation away from oil and gas. As discussed in this report, a number of IOCs appear to be making small steps in this direction, although their key business focus very much remains on oil \& gas. As the IEA (2020a) reported, less than $1 \%$ of capital expenditure is being spent outside of core business areas.

2. In the near term, cleaner operations are key. Therefore, scope $1 \& 2$ metrics are important for minimising upstream emissions. The modelling highlights the impact for example of high carbon intensity gas resources (due to methane emissions) on 
their production levels in a climate-constrained world. Unconventional resources, which tend to require more energy input per unit of extraction, and are more costly, appear unlikely to be exploited in our Paris-aligned case.

3. The modelling does not support the assertion that higher carbon intensity production upstream can be offset by lower emissions downstream (e.g. via higher vehicle efficiency standards). This is particularly the case where these oil products are exported abroad to regions with low efficiency forms of transportation/limited environmental regulation.

4. There is more potential for NOCs to achieve emission reduction from operational emissions, although the incentives to do so might be lower (with far less scrutiny and reporting). Diversification is likely to be more of a challenge, due to the reliance of public budgets on revenues gained. However, a number of high producing countries are vigorously exploring diversification strategies. Such strategies could include massively increasing support for renewable industries, and focusing on areas such as hydrogen production and CCS applications.

5. For the large NOC producers, with the lowest-cost conventional reserves, it is likely that they may be able to continue producing for the longest, as climate policy stringency increases. This will make resources of high carbon intensity unattractive, due to their upstream emissions and typically higher costs.

6. However, given that NOCs hold the largest reserves, risks of stranding for them will be greater in absolute terms. While having reserves that are cheaper to extract and generally less carbon-intensive, IOCs aim to produce reserves with a maximum 30 years ahead time horizon, and many have an even shorter timeframe with ambitious climate goals likely narrowing that further going forward. This means that the overall long-term stranded volumes of IOCs will be significantly smaller than for NOCs. 


\section{References}

Balcombe, P., Anderson, K., Speirs, J., Brandon, N., \& Hawkes, A. (2017). The natural gas supply chain: the importance of methane and carbon dioxide emissions. ACS Sustainable Chemistry \& Engineering, 5(1), 3-20.

BNEF (2109). New Energy Outlook 2019. Bloomberg NEF, London. https://about.bnef.com/new-energy-outlook/

Brandt, A. R., Yeskoo, T., McNally, M. S., Vafi, K., Yeh, S., Cai, H., \& Wang, M. Q. (2016). Energy intensity and greenhouse gas emissions from tight oil production in the bakken formation. Energy \& Fuels, 30(11), 9613-9621.

Cai, H., Brandt, A. R., Yeh, S., Englander, J. G., Han, J., Elgowainy, A., \& Wang, M. Q. (2015). Well-to-wheels greenhouse gas emissions of Canadian oil sands products: Implications for US petroleum fuels. Environmental science \& technology, 49(13), 8219-8227.

Carbon Tracker (2019). Balancing the budget: Why deflating the carbon bubble requires oil \& gas companies to shrink. https://carbontracker.org/reports/balancing-the-budget/

Charpentier, A. D., Bergerson, J. A., \& MacLean, H. L. (2009). Understanding the Canadian oil sands industry's greenhouse gas emissions. Environmental research letters, 4(1), 014005.

Debarre, R., Fulop T and Lajoie, B. (2016). Energy Perspectives - Consequences of COP21 for the Oil \& Gas Industry. GHG Targets and Possible Outcomes. Accenture Strategy Energy

Dupré, S., Thomä, J., Dejonckheere, S., Fischer, R., Weber, C., Cummis, C., \& Srivastava, A. (2015). Climate Strategies and Metrics: Exploring Options for Institutional Investors.[Online] UNEP FI, 2 Degrees Investing and GHG Protocol.

Englander, J. G., \& Brandt, A. R. (2014). Oil sands energy intensity analysis for GREET model update. Department of Energy Resources Engineering, Stanford University.

Ghandi, A., Yeh, S., Brandt, A. R., Vafi, K., Cai, H., Wang, M. Q., ... \& Reedy, R. C. (2015). Energy intensity and greenhouse gas emissions from crude oil production in the eagle ford region: input data and analysis methods. Argonne: Argonne National Laboratory.

Griffin, P. (2017). The Carbon Majors Database: CDP Carbon Majors Report 2017, CDP: London.

ICCT (2010). Carbon Intensity of Crude Oil in Europe. A report by Energy-Redefined LLC for the International Council on Clean Transportation. November 2010.

https://theicct.org/sites/default/files/ICCT crudeoil Eur Dec2010 sum.pdf ICCT (2014). Crude Oil Greenhouse Gas Emissions Calculation Methodology for the Fuel Quality Directive: Report by the International Council on Clean Transportation to the European Commission Directorate-General for Climate Action. 
https://ec.europa.eu/clima/sites/clima/files/transport/fuel/docs/icct crude ghg calculatio $\underline{n}$ methodology en.pdf

IEA (2020a). The Oil and Gas Industry in Energy Transitions. International Energy Agency, Paris https://www.iea.org/reports/the-oil-and-gas-industry-in-energy-transitions

IEA (2020b). Global CO2 emissions in 2019. International Energy Agency, Paris. https://www.iea.org/articles/global-co2-emissions-in-2019

IEA (2020c). Global Energy Review 2020: The impacts of the Covid-19 crisis on global energy demand and $\mathrm{CO} 2$ emissions. International Energy Agency, Paris.

https://www.iea.org/reports/global-energy-review-2020/global-energy-and-co2-emissionsin-2020\#abstract

IEA (2019). Tracking Fuel Supply, International Energy Agency. Paris https://www.iea.org/reports/tracking-fuel-supply-2019

IEA (2018). $\mathrm{CO}_{2}$ Emissions from Fuel Combustion 2018, International Energy Agency, Paris https://www.iea.org/reports/co2-emissions-from-fuel-combustion-20198

IEA (2018b). World Energy Outlook 2018, International Energy Agency. Paris. https://www.iea.org/reports/world-energy-outlook-2018

IHS (2010). Oil Sands, Greenhouse Gases, and US Oil Supply. https://cdn.ihs.com/ihs/cera/Oil-Sands-Greenhouses-Gases-and-US-Oil-Supply.pdf

IPCC (2018), Summary for Policymakers. In: Global Warming of $1.5^{\circ} \mathrm{C}$. An IPCC Special Report on the impacts of global warming of $1.5^{\circ} \mathrm{C}$ above pre-industrial levels and related global greenhouse gas emission pathways, in the context of strengthening the global response to the threat of climate change, sustainable development, and efforts to eradicate poverty [Masson-Delmotte, V., P. Zhai, H.-O. Pörtner, D. Roberts, J. Skea, P.R. Shukla, A. Pirani, W. Moufouma-Okia, C. Péan, R. Pidcock, S. Connors, J.B.R. Matthews, Y. Chen, X. Zhou, M.I. Gomis, E. Lonnoy, T. Maycock, M. Tignor, and T. Waterfield (eds.)]. In Press.

Laurenzi, I. J., Bergerson, J. A., \& Motazedi, K. (2016). Life cycle greenhouse gas emissions and freshwater consumption associated with Bakken tight oil. Proceedings of the National Academy of Sciences, 113(48), E7672-E7680.

Masnadi, M. S., El-Houjeiri, H. M., Schunack, D., Li, Y., Englander, J. G., Badahdah, A., Monfort, J. C., Anderson, J. E., Wallington, T. J., Bergerson, J. A., Gordon, D., Koomey, J., Przesmitzki, S., Azevedo, I. L., Bi, X. T., Duffy, J. E., Heath, G. A., Keoleian, G. A., McGlade, C., ... Brandt, A. R. (2018). Global carbon intensity of crude oil production. Science. https://doi.org/10.1126/science.aar6859

McGlade, C., Ekins, P. (2015) The geographical distribution of fossil fuels unused when limiting global warming to $2{ }^{\circ} \mathrm{C}$. Nature $517,187-190$. https://doi.org/10.1038/nature14016 
McGlade, C. E. (2014). Uncertainties in the outlook for oil and gas (Doctoral dissertation, UCL (University College London)).

Mui, S., Tonachel, L., McEnaney, B. and Shope, E. (2010). GHG Emission Factors for High Carbon Intensity Crude Oils. Natural Resources Defense Council (NRDC). June 2010. https://www.circleofblue.org/wp-content/uploads/2010/08/NRDC-ghg-emissions-reportfrom-unconventional.pdf

Naimoli, Stephen and Sarah Ladislaw (2019). Oil and Gas Industry Engagement on Climate Change, Center for Strategic and International Studies https://csisprod.s3.amazonaws.com/s3fspublic/publication/191003 LadislawNaimoli Oi landGasIndustry WEB v3.pdf

Oil Climate Index. https://dxgordon.github.io/OCIPlus/\#total-emissions [Wang et. al, 2016 http://oci.carnegieendowment.org/\#methodology]

Pacheco, D. M., Bergerson, J. A., Alvarez-Majmutov, A., Chen, J., \& MacLean, H. L. (2019). Characterizing Variability in Oil Sands Upgrading Greenhouse Gas Emissions Intensity. Energy \& Fuels, 33(9), 8907-8919.

Renew Economy (2019) Global divestment movement hits \$11 trillion, pushes for more and faster. https://reneweconomy.com.au/global-divestment-movement-hits-11-trillionpushes-for-more-and-faster-98161/

SEI, IISD, ODI, Climate Analytics, CICERO, and UNEP. (2019). The Production Gap: The discrepancy between countries' planned fossil fuel production and global production levels consistent with limiting warming to $1.5^{\circ} \mathrm{C}$ or $2^{\circ} \mathrm{C}$. http://productiongap.org/

Siirde et al. (2013). Greenhouse Gas Emissions Analysis of Energy Production Processes from Estonian Oil Shale. https://circabc.europa.eu/sd/a/e3685bb5-cdbc-4a94-a39064b6241513ea/15\%2004\%2013\%200il\%20Shale.pdf

Solano-Rodriguez, Baltazar, Steve Pye, Pei-Hao Li, Paul Ekins, Osmel Manzano, and Adrien Vogt-Schilb (2019). Implications of Climate Targets on Oil Production and Fiscal Revenues in Latin America and the Caribbean. Inter-American Development Bank.

https://doi.org/10.18235/0001802

Stephenson, T., Valle, J. E., \& Riera-Palou, X. (2011). Modeling the relative GHG emissions of conventional and shale gas production. Environmental Science and Technology.

https://doi.org/10.1021/es2024115

Tollefson, J. (2013). Methane leaks erode green credentials of natural gas. In Nature.

https://doi.org/10.1038/493012a

UNEP (2015). Climate Strategies and Metrics: Exploring options for institutional investors, 2 deg Investing Initiative.

https://www.unepfi.org/fileadmin/documents/climate strategies metrics.pdf 
Watterson, J. (2014). Calculation of mitigation potential / carbon footprint / Life Cycle Assessment (LCA), including application of 2006 IPCC Guidelines. Paper presented at the IPCC expert meeting, Sofia, Bulgaria

Welsby, D. Modelling uncertainty in global gas resources and markets (forthcoming). (University College London, 2020).

Welsby, D. Modelling natural gas resource uncertainties and markets. (UK Energy Research Centre, 2018). https://ukerc.ac.uk/publications/modelling-natural-gas-resource/

Wood Mackenize (2018). Carbon Intensity: not all assets are created equal. https://www.woodmac.com/news/editorial/carbon-intensity-not-all-assets-are-createdequal/

Zhang, Y., Gautam, R., Pandey, S., Omara, M., Maasakkers, J. D., Sadavarte, P., Lyon, D., Nesser, H., Sulprizio, M. P., Varon, D. J., Zhang, R., Houweling, S., Zavala-Araiza, D., Alvarez, R. A., Lorente, A., Hamburg, S. P., Aben, I., \& Jacob, D. J. (2020). Quantifying methane emissions from the largest oil-producing basin in the United States from space. Science Advances. https://doi.org/10.1126/sciadv.aaz5120 
UCL INSTITUTE FOR SUSTAINABLE RESOURCES ucl.ac.uk/bartlett/sustainable 